\title{
Eski Ǐsrail Hukukunun menşei, hususiyetleri ve Hamurabi kanunu ile olan münasebetleri
}

\author{
Yazan : Hâmide TOPÇUOĞLU \\ Hukuk Felsefesi ve Hukuk Sosyoloiisi \\ Asistanı
}

\section{Konunun açıklanması :}

Israil oğullarının tarihi ve hukuku hakkında mukaddes kitaplardan edinilen bilgiler uzun zaman doğmatik tarihçileri hariçten kaynaklar aramaktan alıkoymuștur. Diğer taraftan yakın zamanlara kadar bu devre ait yeni vesikalar keșif edilememis olduğundan rasyonel düşünen tarihçiler dahi bu mukaddes kitaplardaki haberleri ilmi ve objektik bir gözle incelemekten baska yapacak șey bulamamışlardır. Son zamaplarda yapılan bazı keşifler husysile yirminci yüz yılın başlangıcında Hamurabi kanunlarının keșfi bilginleri lsrail hukukunu yeni bir ıșık altında tetkike sevk etmiş ve varılan neticeler hukuk tarihçileri arasında bir hayli heyecan uyandırmıșłır. limî tarihçiliğin gelişmesi ve tevrat üzerinde filolojik metodlarla yapılan incelemeler neticesinde Israil hukukunun menșei ve komșu hukuk sistemerile olan muhtemel münasebetleri objektif bir tarzda araştırılmağa çalıșılmıștır.

Israil hukukunun menșeini aramak ve peygamberler içinde kanun koyuculuğu ile meşhur olan Musanın tarihi șahsiyetini aydınlatmak ve koyduğu kanunların kendi zamanındaki mevkini ve değerini incelemek bir çok bakımlardan ehemmiyetli olan bir meseledir. Bir taraftan Incil ve Kuran ile ikmal edilmiş olan ahlâki ve hukuki kaidelerin, yani son üçbin senelik medeniyete hakim olan sosyal prensiplerin menșeini teșkil etmesi, diğer taraftan Hamurabi kanunlarının keșfine kadar bilinen en eski yazılı kanun olması hukuk tarihçilerinin nihai tecessüs ve dikkatlerini en sonunda bu hükümler üzerinde toplamıștır. «Evamiri așere» diye bilinen Musanın on emri hemen bütün dinlerde müssterektir ve bu emirlerin zamanımızdan geriye doğru giden bir hukuk tarihi araştırmasında yozilı olarak elimize geçen en eski metni ise tevrattadir. 
1991 - 1902 senelepi qrasında Hamunabi kanunlarınun kesfi hukuk tarihcileri arasinda hir heyeacan uyandumus ve Musa kanunlarundan daho eski bi bukuk sisteminin jzleri bulununca o zamana kadar meçul kalan bir sok

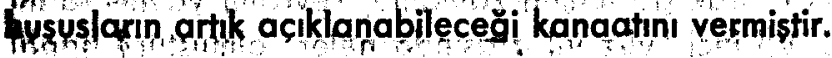

Zirg din ve urk birliğine sahip muhafazakâr ve eski bir kovmin ilk nqzarda tam bir vahdet ve hususiyet arz eden bu hukuk sistemi, bu tarihe kadof adeta nevi sahsına mü hhasur bir sistem gibi telâkkki edilmiști. Bunun ilâhi his mensei olduğu yolundaki doğmatik telâkkiye kapilanlar ise zaten bu iddiada idiler. Diğer taraftan rasyonel düsünen tarihciler nihayet «bu hukuk siskeminin de kendisinden müteessir olduöu bir baska bir sistem mutlâka vardr. Fakat bu gün bunun hangi sistem alduğunu bilemiyoruz» demekten baska bir say yapamyorlardi. Bu fikir ise snerede bir cemiyet varsa orada bir. bukuk vardirs vecizesinin baska bir sekilde ifadesinden ibaretti. Filhakika lsrail oğullarinın da temasta bulunduğu, hattâ kendisinden kopup geldiăi ve*a ilerde münasebete giristiŏi baska bir cemiyet hattâ muhtelif cemiyetler almuștu. Bunları da kendilerine mahsus bir hukuk sistemleri vandı. $O$ halde Israil oğulları da bu sistemlerden müteessir olmus olmalıdurlar denilębilir. Fakat bu umumi hükümlerle birsey aydınlanmıs clmaz.

Su halde bu yazımızda evvelâ lsrail hukukunun menseleri ve hususiyetlaxi hakkındaki arastirma neticelerini, sonıa da bunun en fazla münasebettar olduŏu zannedilen Babil hukuku ile olan alâka ve derecesini incelememiz gerekiyor.

\section{Birinci Bölüm :}

lsgail hukukunun mensei meselesi :

I-Israil oğullarının tarihçesi :

«lsrail hakkındaki ile harici vesika (yani tevrattan gayri) milâdden evvel dokuzuncy, asto ait bir dikili tastr. Bu tosta cizye getiren Jehu elcilari ve kendi djesmanlari arasinda kral Achab'i da gösteren bir Asur kral tarsim edimisfi. Bundan evelki devirler haklundo elimizde ancak lsrail oöullarinin kendi torihheri hakkindaki kiymeti pek suppheli olan ifade ve iddialarundan baska bif sey yokture (i)

Musann (sahsixeti bakkindaki teroddüHter bir takaf) doğum tarihi ise.

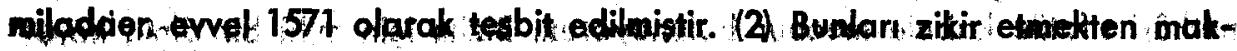

(11) - Denis SAURAT - Histoire des religions, Raris 1933 Sh: 184

(2) Tancrède ROTHE - l'esprit du droit chez les Anciens Paris 1928 Sh: 5 Bu hu-

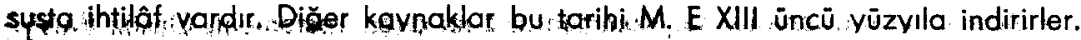


sadımız mevzuumuzun dıșında kalan tarihi bir problemi incelemek değil, sadece Israil tarihi hakkındaki vesika fıkdanını belirtmiş olmaktır. (3)

Musanın doğum tarihi olarak gösterilen zamanla, Tevratin yazilış tarihi olarak kabul edilen M. E. VII inci yüz yıl arasında neler olmuștur? hangi mevzuat ne sekilde isdar edilmiș, nasıl muhafazá edilmiştir? anane ile ve șifahi olarakmı? yazilı olarakmı? bunlar henüz bilinmemektedir. Sonra Israil oğullarının yakın şark milletleri arasındaki eskilik derecesi nedir? iddiaları vechile hakikaten en eski millet bunlar mıdır? Anton Jirku: "Asur ve Babil yazılariyle M:sır hiyerogliflerinin çözülmesile Isail oğullarının tarih, din ve kültürlerinin manzarası tamamen değișmiștir. Şimdiye kadar Israil, eski şarkın bize edebi eserler bırakmıs olan en eski milleti olarak telâkki edildiği halde bu gün, eski ön Asya dünyasının en genç milleti olarak görünmektedir. Uzun zamandanberi Israilin kültürü her bakımdan nevi șahsına munhasır bir olay telâkki edildiği halde artık bu hususta yeni bir ders almak mecburiyeti vardır. Zira Israil bütün his ve fikir hayatı bakımından diğer eski șark milletlerinden bir tanesi olarak tavsif edilmelidir. Yani onlardan, onlarin nev'inden biri olarak,» diyor. (3 a)

Ibraniler kendi cedlerinin Mezopotamyadaki Ur şehrinden geldiğini iddia ederler. Göçebe halde yaşayan lbraniler bir aralık Misırın șark sınırlarında yerleşmişler, Firavunlar tarafından bir müddet nizam altında tutulmuşlarsada bilâhare aradaki anlașmazlık yüzünden tekrar eski bedevi hayatına dönmüșler çölde başıbos dolaşmağa başlamışlardır. Mısırdan çıkıs zamanında bașarında Musanın olduğu iddia edilir ki bu hususlar Tevratin (Huruc) kısmında mufassalan anlatılır. Mısırda tâbi tutuldukları muamele ve angaryalar Ibrani tarihinde acı bir hatıra olarak kalmıștır ve kurtulușlarını bir mucize olarak kabul etmişlerdir. Bilâhara Filistinde yerleşmişler ve Kenan medeniyetinin tesiri alında kalmışlardır.

$$
\text { II-Musa : (Teurat) }
$$

Tevrattaki hükümleri Jahve'ye atfen Israil oğullarına nakleden Musanın - tarihi şahsiyeti hakkındaki kanaatlar muhteliftir. "Bir çok tarihciler Musanın şahsiyetinin bertaraf edileceğine kanidirler. Zira onun hakkında mevsuk olarak hiç birşey bilmediğimizi söylüyorlar. Eldeki tarihi vesikalar Musanin yaşadığı zamandan çok sonraya aittir. Fakat Musa olmadan da Israil tarihi mümkün görünmüyor ve biz onun şahsını vaki farz etmeye ve onu Jahve'nin hizmetkâri sıfatile kabule mecbur bulunuyoruz. Bizim için milli bir dinin koru-

(3) Kaynakiar ve tarihçe hakkında fazla izahat için bak: Dri. Coşkun Üçok - Türk Shukuk tarihi dersleri Istanbul 1946 Sh 46 - 49.

(3a) Dr. Anton Jirku-Altorientalischer Kommentar zum alten Testament. Onsöz Sh.V: 
cusus ve bir kurtulusun kahramani olarak Musayi tanimak zaruridit. Esasen diger sami dinlerde de b" gibi misaller pek çok görüimüștür. Böytece kendï tarihlerinin mebdei hakkında tbranilerin sehadetini kabul etmek makul düșer." (4)

\section{III - Ahdiatik (Tevrat)}

Yahudi ve hiristiyan ananasi tevrałın Musa tarafindan nakil olunduğunu ve milâddan evvel $X V$ inci asırda yazıldığın kabul eder. Rasyonalistlerse bilâkis bu kifabın Musadan çok sonra tanzim edildiğini kabul ederler. Teü-i ratın bizzat Musa tarafından tanzimi hususunda daha Eski ve Orta çağlar-: da dahi şüpheler uxanmıştur. Bu muammayı çözmek için iki tez artaya atılmıştır. Bunlardan biri (vesikalar - des Documents) denen nazariyedir ki bunun da esası Tevrati teşkil eden ilk bes kitabın (Esfarı hamse: tekvinulmahlukat + Huruc + Laviluler + adat + tesnixe) daha eski olan iki vesikadan: terekküp etmis olduğu iddiasıdır. Bu neticeyi Allah mefhumunun bu bes kitapta (5) başka başka kelimelerle ifade edilmis olmasından çıarhyorlar.: Filhakika evamiri aşerede Allah mefhumu (Yahve) kelimesile ifạde edildiği halde, en eski parça olan ahidde '(6) (ki ikinci kitap olan hurucun 20 - 24 üncü bablarıni teşkil eder) ayni mefhum Elohim kelimesile ifade edilmektedir. Böylece bu iki kısmın ayrı ayrı müellifler tarafından kaleme alındiğı neticesine varılmaktadır (7) Bu tez Graf ve Reuss ve Wellhausen tarafindan inkisaf ettirilmiștị. Diğer teze (ekler veya ilâveler = Compléments ou Suppléments) tezi denir ki buna göre ilk bes kitap haddi zatinde pek eski iptidai. bir metindir fakat muhtelif zamanarda genişletilmiş ilâvelere maruz kalmıștır.

Tevratın ne zaman tedvin edildiği meselesi muhtelif kısımları hakkında" ayn ayrı hal suretleri kabul eder. En eski kısımlar milâddan evvel $X$ uncu. yüz yıla kadár gider. Daha yeni olaniar ise bazı müelliflere göre milâddan evvel VIII inci bazılarına göre de VI ınca yüz yıllara aittir ve tevratin múhtelif bölümleri milâdden evvel VI inci yüz yilın sonlarına doğru tek bir kitap hálinde toplänmıştır.

(4) - Denis SAURAT. sh: 187

(5) - Pentateuque: Yukarıda adları sayılan bes kitaba. Yunan mütercimleri tarafindan verilen isim sesfarı hamses

(6) - Bundesbuch

(7) - H. B. WITTER - Jura Israelitarum in Palestinam 1711

J: ASTRUC Coniecture sur les mémoires originaux dont il parait que Moyse s'est servi pour composer le livre de la Genèse. 1753. 
622 tarihli olan bu Josia kanunnamesine (8) miladden evvel 422 senesinde nihayet Priester Kodex (Ruhban kanunu) eklenmistir ve tarihi bir mukqddimesi vardır. Bu ikinci kitabin 35 ila 40 inci babları sonradan eklenmistir. Hülasa Tevratin bütünü miladden evvel XV - VII yüz yıllar arasında muhtelif eklemelerle meydana gelmiștir ve bu günkü şeklini aşağı yukarı milâddan evv $=1400$ senesinde almışır. Tevrat ve Incil tann ile insanlar arasindaki bir ahdi ifade ettiğinden bu mukaddes kitaplara gerek yahudiler gerek eski hiristiyanlar «ahid - Testamente» demişlerdi. II inci asırda bu karışıklığı Hğı izale için yahudilerin ahdine "ahdi atik», Hiristiyanların ahdine de "ahdi cedid» denmiștir.

Tevratin büyük bir kısmı ilk defa ibranice olarak yazılmıștır. Birkaç dane de ermenice ve yunanca yazılmıștır. Incil ise doğrudan doğruya yunanca yazılmıștır. Tevratın yunancıya tercemesi milâddan evvel III ve II inci asırlara tesadüf eder. Bunun adı «Septante» dir ve yahudilerle protestanlar buna kıymet verirler. Katolik kilisesi ise milâdi 392 ve 410 yıllarında yapılan ve. "Vulgata» adını taşıyan latınce tercemeyi doğru sayar.

IV - Tevrattaki hukuki hükümlerin yerleri :

Tevrattaki kanunların en eskisi (Huruc = Exodus) in 21 - 23 üncü bablerini teșkil eden «Bundesbuch» ahid denen kısmında bulunur. Bu kısım galip bir ihtimalle eskiden kalmıs belki pek eski bir örfüadet hukukunun tedvini olarak telâkki edilebilir. Fakat yalnız tedvin ile iktifa etmez ayni zamanda tıpkı (tesniye = Deuteronomium) in 12 inci ve müteakip bahislerinde olduğu gibi eski hukuku islahı da istihdaf eder.

Bundan başka (tekvinulmahulukat $=$ Genisis) deki birçok hikâyeler Tevrat zamanındaki aile hukuku için ehemmiyetlidir (9). Tesniyede siyasi teşkilâta, aileye, ișe, yabancı ve fakirlere yapılacak muamelelere, mülkiyete, mukavelelere, tazminata müteallik daha tafsilâtlı hükümlere rastlanır. Mamafi tevrattaki hikâyelerin, hattâ hukuki kaide seklinde kaleme alınan cümlęlerin dahi ehemmiyetini pek cüzi telâkki edenler de vardır.

Meselâ Tevrattaki hukuki hükümlerin yeknazarda tecanüssüz ve gelișigüzel bir manzara arz edişine temas ederek bu halin sebebini muhafazakâr ve ananaperest olan Ibranilerin hukuki inkişafa musait olmamalarında bulanlar vardır : (10) içinde üç ayrı kanununamenin birbirinden ayırt edilebil-

(8) - «Deuteronomium - tesniyes kanunun ikinci defa tekrari demektir

(9) - Martin DAVID - Zur Forschungsmethode auf dem Gebiet des biblischen Rechts. 1925. Korrespondenzblatt der Akademie für die Wissenschaft des Judentum 1925 V1: $26-42$

(10) Tancrède ROTHE : Sh: 9 
diği Tevrattaki kanunlar mecmuası, asıl manada organik bir tekâmülün müsahedesine hemen hiç müsait değildir: bazı hükümler tekrarlanır, bazılarının arasında tenakuzlar görünür ve birbirini hükümsüz bırakırlar. Bununla beraber hiç kimse bunları kaldırmak cesaretini gösteremediği için bunlar bugüne kadar birbirlerile yanyana yașayıp kalmışlardır. Bundan mada bu kanunların mevzuları da mahduttur: ibadet, ceza hukuku, aile durumu, adli teşkilât... Iște hèmen hemen hepsi bu. Fakat bunların içinden hiç birisi (tesniye) deki kraliyet hukukuna mütaallik ehemmiyetsiz cümlecikler kadar müellifin hukuki maksadlarındaki görüş darlı̆̆ını meydana vurmaz. Bunun âmme hukuku ile hiç bir alâkası yoktur. Zaten hiç bir mücerret prensip, hiçbir mantıkî nizam bu mecmuada bulunmaz. Esasen bu, ancak müşahhas hadiselerin hal suretlerinin bir silsilesinden başka birşey değildir. Burada Hahamların «Casuistique» $\mathrm{i}$ ancak tohum halinde mevcutiur... Vakıa Tevratta bazı hikâyelerin bulunduğu doğrudur ve bu hikâyelerden hukukun nasıl tatbik ve icra edildiğini bilfiil görebilmek ihtimali vardır. Fakat bu da okadar emin bir yol değildir. Herşeyden evvel ahdiatik bir kitaptır, daha doğrusu bir kitaplar mecmuasıdır. Yani okuyucular üzerinde müessir olmak maksadile muhtelif vesikaların kaleme alınarak ișlenmesinden ibarettir. Bunu yapanlar da umumiyetle hukukcu değillerdi. (Tekvinulmahlukat) bize rahiblerin erazisi hariç olmak üzere bütün Mısır topraklarının Firavine aidiyetinden bahsederken bir hukuki hükmü bildirmiş değil, belki sadece bir vakiayi kabataslak bir şekilde hikâye etmiștir» mamafi Tevrat hükümlerinin tarihi mevsukiyet derecesi ne olursa olsun (11) en sonunda kendisine baș vuracağımız yegâne kaynak da yine bundan ibarettir. Bu itibarla bunun ehemmiyetini küçümsemek ile hiçbirşey hal edilmiş olmaz. Ancak ilmî süpheciliğin ikaz ve ihtarları hatırlanmış olur.

V - Israil hukukunun araștırılmasında metod :

Tevrat ile onun sonradan yapılan muhtelif tefsirlerinden (12) başka esaslı bir vesikaya sahip olamadığımıza göre elde mevcuł olan bu kıt malzeme ile is yapmak zarureti var demektir. Bu vesika buhranını belirten Marin David şöyle der : "ahdiatik zemanından bize gelmiş olan vesikalar hemen hemen yok gibidir. Hukuk tarihinin bu boșluk yüzünden ne kadar ıstırap çektiğini, Babil ve Asur mukavele vesikalarının kendi zamanlarındaki hukukun tetkiki için ne kadar ehemmiyetli olduğunu bilen herkes takdir eder. Zira eski şarka taalluk eden hukuk meselelerine mütedair hemen hiç bir tet-

(11) - Archives d'Histoire Oriental. 2; 1938. Sh: 44: (Introduction bibliographique à l'Histoire du Droit du peuple Hebreu)

(12) - Dr. Coskun UCOK - Sh: 48 
kik yokłurki, esasında vesikalara istinad efmiş olup da, kanun hükümlerinden ancak tâli derecede istifade etmiş olmasın. Zira kanun hükümlerinin tekâmül silsilesi emin bir surette bize kadar varmamıs olduğu takdirde, uzun zamandanberi tatbikatta hiç kullanılmamıs veya teamül ile ortadan kalkmiş yahut elimize geçmemiş olan diğer hükümler vasıtasile hükümden düșürülmüs olan kaidelerin ancak tarihi bir hatıra olarak baki kalmış olması ihtimali daima göz önünde tutulmalıdır. Iște bu sebepten dolayı meri hukuk hakkındaki muşahhas vesikalar, ne kadar mufassal bir șekilde kaleme alınmıs olursa olsun mücerret bir kanun metninden daima daha iyi daha emin bir fikir vermekłedirler. Bașka tabirle; ahdiatikteki hükümlerin hakiki manasını göstermeye elverișli ve o zamandan kalmış olan büyük vesika hazinelerinin keșfi halinde Tevrat hükümlerinin tetkik tarzı bir anda tamamen değișebilit.» (13)

Vesika kıtlığınin doğurduğu ile netice hukuk tarihi araştırıcısını «inductif» metoddan «déduchif» bir metoda götürmek ve bazı genellemelerden harekete sevk etmek olmusiur. Bu genellemeler ise umumi hukuk tarihi ile mukayeseli hukuk metodlarından alınmaktadır. Nihayet filolojik metodlardan da yardım isłemek cihetine gidilmiștir. Umumi hukuk tarihinde, muayyen bir kültür seviyesinde bulunduğu malum olan bir cemiyetin hukukunda bu cemiyetin ırkî ve millî vasıflarından mücerred olarak ayni seviyedeki dĭger cemiyetlerle müșterek veya sabit bazı karakterler tesbit edilebileceği neticesine varılmıștır. Meselâ kadim hukuk sistemlerinde satıs sözleşmesi ayni mümeyyiz vasıflarl göstermektedir: Her iki edanın ayni anda mübadelesi, semenin tediyesinin mal üzerindeki mülkiyetin nakli için șart teşkil etmesi gibi. Belki bu, beyi akdinin trampadan doğmuş olmasından ileri gelmiștir. Yani âkidler kendi ihtiyaçlarını ayni anda tatminde ısrar hususunda birleșmișlerdir. Yahut ta mamelek menfaatlarını himaye edecek kuvvetli bir âmme kudreti mevcut olmadığı için mukavelelerin ifasını ileriye talik imkânsız görülmüș olabilir. Iște, her ne olursa olsun beyi akdi hakkkındaki bu mümeyyiz vasfın Israil hukukunda da mevcut olduğu neticesine varilabilir. Halbuki Tevratta bu hususta pek az delil vardır. Tekvinin 23 ncü babinin 16 ve 17 inci cümlelerin-

(13) - M. DAVID - Sh: 29. Keza Archives d'Histoire du Droit Oriental Sh 144: «Tevrat ve incile tealluk eden hususlarda Hukuk Tarihçilerinin mutlak bir vesika fikdanı içinde bulunduklarını müșahede etmek lâzımdır»

Aynı eser Sh: 147: "Sark tarihine mütedair kessiflerle biz fazla ifsad edilmis durumdayı. Halbuki bu kesifler bize serhden ve islenmeden mahrum bazı vesikalar bahsetmekten baska birsey temin etmemistir. Vakıa bunların mukaddes kitabdaki kanunları hikâyeleri ile aydınlatıkları ve bizi İsrailin yaşadığı sosyal muhite soktukları doğru. dur, keza tarihî manadan mahrum meinler Misır ve Babil vesikalarivle temas neticesinde biraz tarihî bir renk kazanmıslardır, bununla beraber lbrânî Hukukuku hakkındaki tetkiklerin bu vasttalardan o kadar istifade etmediğini de itiraf etmek lâzımdır.» 
de Machpela mağarasının satışından bahsedilirken paranın verilmesini müteakip mülkiyetin müsteriye intikal ettiği zikir edilir (14). Bundan bașka mukayeseli hukuk metodlarından da istifade kabildir. Şu kadarki mukayese sayesinde farklı sistemlerde birbirine benzeyen kaideler bulup çıarmak mutlâka bir gaye haline gelmemelidir. Bu metod itidal ile kullanılmalıdır. (15).

Kadim hukuk sistemlerinin birbirile mukayeseli bir şekilde tetkiki umumiyetle hukuk tarihçilerini benzerliklere varmaya meyil ettirir. Çünkü tarkliliklar ve tezadlar karșisında kalınınca bunların da kendilerine has sebeplerini bulup çıarmak icap ediyor. Bu sebeplere varılamayınca da hukuk tekâmülïndeki boșluklar doldurulamıyor, dolayısiyle araștırıcı kendisini tatminsiz kalmıs hissediyor. Bu itibarla fazla tełkik yapmadan zahiri benzerliklere dayanarak verilmiş aceleci hükümler hukuk tarihinde pek tehlikelidir. Zira bu hükümlere bir hakikat nazarile bakılmağa bașlanınca onların üstünü örttükleri boşlukların araștırımasına sed çekilmiş olur. Aslında henüz hakikat sahasina çıkarılmamış olan bir husus sanki zaten malûm ve mekșüf bir șeymiş gibi telâkki edilir. "Ahdiatik ile eski şarkın diğer eserleri arasında yapılacak bir mukayesede zuhuru ihtimal dahilinde olan muvazatın muhtelif dereceleri hakkında her hangi akidevi bir kanattan uzak kalmalıdır. Burada esas itibarile üç imkân bahis konusu olabilir: israilin doğrudan doğruya veya dolayısiyle daha mütekâmil diğer kültürlerin tesiri alłında kalmış olması mümkündür. Yahut müşterek bir benzerlik varsa, bunun sebebi müșterek bir sâmi menșe olabilir. Yahutta arłık sadece kıyaslar karșısında bulunuyoruz demektir ki bu gibi benzerlikler birbirinden müstakil olarak zaten muhtelif milletlerde meydana gelebilir. Bazan bu ihtimallerden birini veya diğerini tercih güç olur. Fakat bu okadar mühim bir şey değildir çünkü her halde bahis mevzuu olan benzerlikler müșterek bir millet ve kültür dünyasindan ileri gelmektedir» (15 a) ticeler :

VI - Israil hukukunun menşei hakkında ilmi metodlarla elde edilen ne-

A - Mukayese metodu : Evamiri aşerenin menşei hakkındaki kanaatlar muhteliftir. Müelliflerin bir kısmı bunun tanzimini Musa devrine affeder ve orijinal bir eser olarak kabul edersede bu görüse iltihak için icbar edici bir delil yoktur (16) Evamiri așerenin medeniyet seviyesi itibarile milâdden

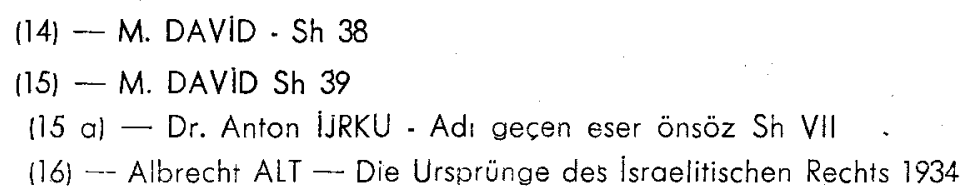


evivel 1500 senelerinde kaleme alınıp alınmayacağı hususunda da fikirlerde ayrılık vardır. Bir kısmı metin olarak değilse de prensipler bakımından Musaya kadar vardığını kabul ettiği halde diğer bazı müellif́ler metnin tam olarak Musa farafından ortaya konduğu fikrindedirler. Bunlardan Anton Jirku iddiasına mesned olarak milâdden evvel 1500 senelerine kadar geri götürülebilen eski Mısır ve Babil yazılarında da ayni emirlerin başka şekiller alında tesbit edilmiş olduğunu ileri sürüyor. Yani evamiri aşeredeki fikirler Musadan çok daha evvel mevcut ve malûmdu diyor. Musanın bunlardan müteessir olup olmadığı meselesinde de üç noktaya işaret ediyor : (17)

a - Evamiri aşerenin dördüncü ile onuncu emirleri arasındaki hükümler birbirinden tamamen müstakil olarak dünyanın muhtelif yerlerinde meydana gelebilir bunlara menşei aramağa lüzum yok.

b - Musa bu Babil ve Misır yazılarından ilham almıs olsa bile, bu yazılarda pek çok «magiques» fikirler vardırki, evamiri aşerede bunlara tesadüf olunmamaktadir.

c - Her halde Musanın oriiinal eseri, cihanşümül ve insani mahiyette olan bu hükümleri birinciden üçüncüye kadar olan emirlerle mukaddes kılmak ve diğer yedi emri bu ilk üç mukaddes emrin bir neticesi olarak göstermekten ibarettir. (18)

(17) - Dr. Anton JIRKU - sh 89
(18) - Evamiri asere : huruc. Bab 20 cümle $3-17$
3 - Huzurumda senin gavri Allahların olmasın
(4) - Kendin için put yapmayasın. Ne yukarıda semade, ne aşağıda zeminde, ne zemin altında sularda bulunan seylerden nic birinin suretini yapmayasın. Anlara secde ve ibadet etmeyesin zira ben senin Allahın Yahve bana bugz edenlerden pederlerin günahını oğullarda üçuncü ve dördüncü nesle kadar aravan gayyur allahım ve beni sevüp omirlerimi hifz edenlere bin nesle kadar inavet ederim

7 - Allahin olan Yahve'nin ismini beyhude vere zikir etmeyesin zira Yahve kendi ismini beyhude vere zikir edeni tebrive etmez.

8 - Rahat gününü takdis için anı hatırinda tutasın.

9-Altı gün çalısıı her isini isleyesin.

10 - Fakat yedinci gün senin allahın olan Yahve'nin rahat günüdür ne sen, ne ağlun ne kızın ne kulun ne cariven ne hayvanın nede kapularının dahilihde olan misafirin hic bir is islemeyesiniz.

11 - Zira Yahve altı günde semavi ve zemini ve denizi ve anlarda bulunanın kôffesini halk edip vedinci günde istirahat evledi bu cihetle Yahve gününü mübarek kilip takdis eyledi.

12 - Pederine ve validene hürmet edesin taki senin allahın olan Yahve'nin sana verdiŏi diyar üzerinde ömrün uzun ola.

13 - Katil etmiyesin
14 - Zina etmiyesin
15 - Sirkat etmiyesin 
Ayni müellif Tevrattaki en eski kanun mecmuasını teşkil eden (Ahid = Bundesbuch) in hakikaten Musanın eseri olması ihtimalini, yeni keşfedilen yøsikaların kuvvetlendirdiğini söylüyor. Mısır ve Babil yazılarile bunlar arasında bazı müșabehetler buluyor :

1 - Harici șekil : Israil kanunlarının büyük bir kısmındaki hükümlerin bir de dıs çerçevesi vardır. Yani bir mukaddime ve bir hâtime bulunur. Ayni hususiyet Hamurabi kanunlarında da vardır. Tıpkı Yahve'nin bașta kendisinden bahsetmesi gibi Hamurabi de kanunun bașinda kendisini ve bu kanunları ısdar sebebini anlatır. Sonra bütün diğer eski şark kanunları gibi bunlar da bir (eger=ki) kelimesile bașlarlar ve bu bakımdan müellif hurucun 21 inci babinin $1,11,14,18 . .22$ inci cümlelerini keza 22 inci babinin 16 ve 23 üncï babinin 4 ncü ve beşinci cümlelerinin bizzat Musaya ait olduğunu ileri sürer. Mamafi bu fikrinin bazan reddedildiğini de kayıt eder.

2 - Eski Asur ve Sümer kanunlarından anlaşılacağı üzere Hamurabi kanunları bizzat Hamurabi tarafından ısdar edilmiş ve kaleme alınmış değildir. Ayni hususiyet Musa kanunları hakkında düșünülebilir. Yani müellifin fikrince Musa da malzemesinin büyük bir kısmını bașka kaynaklardan almıstır. Cü̈nkü milâdden evvel iki bin senesinde Hamurabi hakkında vesikalarla isbat edilebilen bir husus, milâdden evvel binikiyüz senesinde evleviyetle Musa hakkında da kabul olunabilir.

3 - Nihayet en mühim mesele bu Tevrattaki hükümlerin Sümer, Eti, eski Asur ve Hamurabi kanunlarının muhtevalarile olan müşabehetindedir. Bu müşahebeti tebarüz ettirmek için müellif șerhin 93 üncü sahifesine bir mukayese cedveli ilâve etmiştir.

Fakat bütün bunlar yine daima neticeden sebebe varmağa çalışmaktan benzerliklerden başka bir malzeme olmadiğından bunlara müstenid istidlâl ve muhakemelerde bulunmaktan öteye geçememektedir. Nitekim ayn mukayese metodile hareket eden Puukko da eski şark hukuk sistemlerinin benzerlik noktalarını tesbit ile bir neticeye varmak istemiștir. (19). Bu müellifin tesbit ettiği benzerlikler șunlardır :

16 - Komsunun alevhinde valan sehadet etmivesin

17 - Komsunun hanesine tama etmiyesin, komsunun zevcesine ya kuluna ya cariyesine ya öküzüne va merkebine ve komsunun hiç bir seyine tama etmiyesin. 11885 de Amerikan Bibl şirketinin yaptırdığı türkçe tercemeden alınmıșır|

(19) - A. F. PUUKKO - Die Altassyrischen und Hetitischen Gesetze und das Alte Testament: Studia Orientalia: 1: Helsingfors. 1925. Sh: $125-166$ 
1 - İhtiyar heyeti Israililerde şehir kapısında, Asurilerde saray kapısında oturur.

2 - Hâkimin otoritesini muhafaza için hem Ełi hem Israil hukukunda hükümler vardır. Mahkemenin tahkiri her iki mevzuata göre de idam cezasını müstelzimdir. Hattâ Kral mahkemesinin tahkiri suçlunun bütün ailesinin katlini icap ettirir. (20)

3 - Süpheli hallerde Ordal, e müracaat keyfiyeti hem Tevratta, hem Eti ve Asur kanunlarında kabul edilmiștir ve daima zina hakkındadır (21)

4 - Ferdi kısas prensibi, herkesin kendi fiilinden mesuliyeti esası hem Israil hem Asur hukukunda mevcuttur. (22) Bu prensip Eîi kanunlarında yoksa da miladden evvel 1500 senelerinden kalma bir mahkük yazıda bir Kral oğlunun suç ișlemesi halinde başının kesileceği fakat karısına veya çocuklarına ve evine her hangi bir fenalığın yapılmayacağı bildirilmektedir (23)

5 - Hataen öldürme ile kasdî öldürme arasında gerek Sümer, gerek Eti ve gerek Israil hukukunda tafrikler yapılmıștır.

6 - Döğüşen erkeklerin bu esnada hâmile bir kadının çocuk düșürmesine sebebiyet vermeleri halinde muayyen bir para cezasına çarptırımaları bürün șark hukuklarında kabul edilmiș bir esastır (24)

7 - Keza iarlalar arasındaki hudut taşlarının yerlerini değiștirmek bütün eski şark kanunlarında cezayı icap ettirir (25) ve bütün bu eski kanunlaida hudutların kudsi bir mahiyeti vardır ve onlara karşı içlenen suç yalnız insanların mülkiyet hakkına tecavüz değil ayni zamanda Allaha karși da ișlenmiş bir günah telâkki olunur. Verilecek ceza da tazminattan başka en ağır dayak cezası olan yüz derneği vurulmasıdır.

8 - Sihirbazlik, Asur, Babil ve Eti ve Israil kanunlarında menedilmiștir. Bunların kaleme alınıs şekilleri farklıdır (26)

(20) - Eti konunu II s 58, Tevrat: tesnive babı : 17 cümle 12 «amma her kim ki magrurane hareket edüp Allahın Rabbe orada hizmet etmek için duran kâhinini veya hakimini dinlemezse o kimse ölecektir

(21) - Etj kanunu $\S: 132$, Asur kanunu $\S: 17,22,24$, Tevrat, âdat babi: 5 cümle II ve devam!.

(22) - Asur kanunu $\$ 2$. Tesnive : 24,16

(23) - Revue Historique de Droit Français ef étranger III. 3-1924 Juillet-Septembre:

(24) - Huruc. 21 : 22-24 Asur K: \$ 49 Eti K. I \$ 17 Hamurabi \$ 209, 210

(25) - Tesnive : 19. 14. 27. 17: Eti K: 11: $\$ 53,54$ Asur K: IV 11-19

(26) - Huruc. $22: 17$. Tesnive : 18: 10 Asur K: $\$ 47$ 
9 - Nişanlı bir kıza tecavüz suçunda bütün eski kanunlarda erkek suçlu kız suçsuz telakki edilir. (27) fakat bu, suçun, sahrada ișlenmesi ve imdada çağırmanın beyhude olması halindedir. Sehirde işlenir de kız imdat istemezse ikisi de recm edilir. (28)

Bu bakımdan Tevrat hükümleriyle Asur ve Eti kanunlarında bazı farklar görülürse de hakikatte aykırılik yoktur. Meselâ Tevratta yalnız nişanlı bâkireden bahsedildiği halde Asur ve Eti kanunlarında karı hakkında hükümler vardır. Fakat esas itibariyle her üç hukuk sisteminde de evlenme bir beyi mukavelesine benzediğinden nișan akdinde verilen semen dolayısiyle kız artık hukuken evli kadın durumuna girmiş addolunur.

10 - Levirat evlenmesi Yalnız Tevratta değil, Asur kanuniarında da vardır. Hattâ burada yalnız ölen erkek kardeșin karısı değil, ölen evli kadının kız kardeși de alınır. Keza bu da nişan mukavelesinde verilmiş olan semenin karșılığı olarak izah edilebilir. Yani semen karșılığı olarak verilen ilk kız ölürse, ailesi diğer bir kızı onun yerine damada verecektir.

Bütün bu tahmini münasebetlerden ilmi tarihcilik bakımından müsbet bir neticeye varmak güçtür. Muhtelif șark hukuk sistemlerindeki benzerlik cuğrafi ve ırkî müșabehetin tesirile de izah edilebilir. Fakat hiç bir zaman müșahhas hukuk kaidelerinin sarih ve katî bir șekilde muáyyen menşelerini tesbit için bu izahlardan istifade edilemez. Israil hukukunun yegâne vesikası olan Tevratla hemzaman diğer vesikalär bulununcaya kadar yine filolojik metodlarla bu tek vesika üzerinde işlemekten başka çare kalmamıs gibidir. Filhakika bu metod umumi mukayese metoduna nazaran diaha kandirsc ve makul gibi görünmektedir.

B - Filolojik inceleme ve nevi veya șekil bakımından tarihi araştırma metodları ile varılan neticeler :

Filologların hareket noktası su olmuștur. Dıștan bakıldığı zaman edebi bir vahdet arz eden Tevrattaki hikâyeler muhtelif zamanlara aittir. Bu hikâyeler gibi zikri geçen hukuk kaideleri de başka başka zamanların mahsulü olmalıdır. Daha doğrusu tevratta toplanan kaideler bir defada ve yeni olarak ısdar edilmiş bir nizamlar mecmuası değildir. Israil hukukunun menşeleri adlı yazısında bu işle inceden inceye meşgul olmuş olan Albrecht Alt aynen șöyle demektedir "Filolojik çalışmaların neticesinde gerek şekil ve gerek muhteva itibarile eserde az çok ehemmiyetli irtibatsızlıklar tesbit edilmiş-

(27) - Tesnive : 22,25 Asur $K \S 12$, Eti $K \| 1$ \& $8 \overline{5}$

(28) - Tesnive : 22: 24 Hamurabi $\$ 129$ 
tir. Bundan çıkan netice, Tevrati meydana getiren müellifin eski örnekleri kullanırken kısmen buniarın hususiyetlerini bozmus isede tamamen bu örnekleri bertaraf edememiş olduğudur. Tevratın en eski kısmında yani Bundesbuch'de bu durum așikârdır. Zira birbirinden farklı menşelerden gelen parçalar aralarında hiç bir irtibat olmadan eklenmiş bir șekilde yan yana durmaktadırlar. Tesniye ise Musanın söylediŏi bir veda nutku șeklinde kaleme alınmıșıı ki böyle bir șekil hukuk kaidelerinin yazılmasında mutad değildir. Hattô hukuk kaidelerinin arasında vaızlarda söylenmesi mutad olan ihtarlar ve tenbihler de vardır. Netice olarak şunu tebarüz ettirebilirizki Tevrattaki hukuk kaidelerine mütaallik kısımlar tarz ve derece itibarile birbirlerinden farklı iselerde haddi zatinde bir adaptation eserinden bașka bir şey değildirler. Bincenaleyh Israil hukukunun menşeleri bu hukuk kaidelerinin ötesindeki bir sahada aranmalıdır. Tevrattaki hukuk kaidelerinin oriịinal mahiyette olmaması hayreti mucip bir olay değildir.

Çünkü galip ihtimale göre milâdden evvel yedinci yüz yılda kaleme alınmıs olan tesniye bir restorasyon devrinin eseridir ve bütün bu gibi devirlerde olduğu gibi o zamanda da eskiden kalma halk ve hukuk nizamın modern zamana uygun bir şekilde ihya etme teșebbüsü gayet tabii görülmelidir. Bunu takip eden yüz ylllarda, husüsile Babil ve daha sonra fars hakimiyeti zamanında restorczyon ruhu bilhassa kuvvetli idi. Bu ruh esas itibarile Babillilerin tazyiki altında yalnız nazarî sahada ifadesini bulmus olmakla beraber Farslarm siyaseti bu ruha bir tatbikat sahasını da bahșetmiști. Çünkü Asur ve Babil tarafindan takip edilen siyasete tam aykırı olarak Farslar kendilerine tabi olan milletlere siyasi saha haricinde hususile ibadet ve hukuk sahasında geniş bir muhtariyet hattâ Devlet yardımı bahş etmişlerdi. Birinci Darius eski Misir hukukunu M. E. 519 - 503 senelerinde yerli mütahassıslara tedvin ettirdiği gibi bundan birkaç sene sonra birinci Artakserses kendi hizmetinde bulunan yahudi kâtibi Esra'ye gök tanrının yani Yahve'nin kanununu Kudüste ve Juda eyaletinde ilân ettirerek yahudi cemiyetine sağlam bir hukuk temeli kurmak selâhiyetini vermiștir. Iște bu eser muhteva itibarile eskiden kalma Israil hukukudur. Yapılan yeniliklere gelince, bunlar esas itibarile şekil bakımından ehemmiyetlidir. Esas bakımından ancak eserin eski ruhunu bozmayacak mahiyette olan değişiklikler yapılmıştır. Demek ki Tevrattaki hukuk kısımları restorasyon cereyanlarının hususi ihtiyaçlarından doğma neticelerdir. Binaenaleyh tarih ilmi, Filolojinin bulduğu neticeleri teyid etmektedir.» (29)

Ayni müellif filolojik mefodun da gayri kâfi olduğunu çünkü ele geçecek vesikalar ne kadar eski olurlarsa olsunlar hukukun doğumuna nisbetle

(29) - Albrecht ALT : adi geçen eser. 
daima yeni kalacaklarını söylüyor. Çünkü hukukun doğumunun edebi faaliyetin değil, hayatın bir eseri olduğunu ve edebi faaliyete tekaddüm ettiğini hatırlatıyor. Su halde en eski kökleri bulmak için ne yapmalıdır? Edebi sekillerden evvelki durumları nasıl keșif etmelidir? Iște burada «nevi veya sokil bakımından tarihi araștırma metodu» imdada koşmaktadır. Bu metodun esası sudur : Kendi hayatını yașıyan her münferid edebiyat nev'i içinde daima muayyen bir muhteva, muayyen bir ifade șekli ile sıkı bir surette bağ lanmıs bulunur. Bu karakteristik bağlanmalar müellifler tarafından sonradan ve keyfi olarak ișlenmiş olan mevzulara giydirilmiş olmayıp belki ta eskidenberi yani bütün yazılı edebiyattan evvelki sözlü «tradition» da bünye itibarile mevcuttur. Zira bu karakteristik bağlanmalar hayatın mutad olarak tekrarlanan hadise ve ihtiyaçlarına uygundur ve iște bu münterif neviler bu ihtiyaç ve olaylardan doğmuștur. Müellif kendisinin bu metodu Israil hukukuna tatbik eden ilk tarihçi olduğunu söyler ve Tevratin en eski kısmı olan Bundesbuch'u ele alır. (30)

Filhakika Tevrattaki hukuk kaideleri birbirinden ayrı iki nevi cümlecikler halindedir.

Bir kısmı münferid hadiselere bir hal sureti bulma şeklinde mücerred cümleler halindedir. "Eğer falan hadise vukua gelirse filan müeyyide tatbik edilir» gibi. Bunlara "Casuistique» nevi denir. Buna mukabil yine ayni ahidde öyle cümleler vardır ki burada mücerred hal suretleri değil kesin emirler tecelli eder: «Sen şöyle yapmalısın, șunu ișle, șunu ișleme», «Ben böyle istiyorum, sen bunu yapmalısın" gibi. Bu iki ayrı nevi iki ayrı kökten gelmedir. Nitekim aşağıdaki tafsilat da bu iki farklı edebî nev'in birbirinden pek farkłı muhtevalara tekabül ettiğini gösterecektir.

1 - «Casuistique» hükümler :

Ahdin aşağı yukarı yarısı bu șekildeki hükümlerle doludur. Tasnifleri iyidir ve bir vahdet arz etmektedirler. Bu kısmın evvelce müstakil olan baska bir eserin ancak bir kısmını teșkil ettiği bugün umumiyetle kabul edilmiştir. Bu hükümlerin mümeyyiz vasfı «eğer» «kj» edatiyle başlamalarıdır. Maddede bahis konusu olán hadisede rol alacak șahıslar daima üçüncü sahıs seklinde ortaya çıkarlar. Yani vakanın faili, davacısı, dava olunanı, yargıclar ve nihayet ülôhiyet hasılı hepsinden üçüncü şahıs olarak bahsedilir. Kanun koyucunun sübjektif «ben" i veya münferid hukuk süjelerine karøı kullandığı «Sen» zamirleri ne zaman ortaya çısa ilk neviden olan bir cümlenin bir bozuluşu karşısında kalırız. Yani ahiddeki hukuk kaidelerine

(30) - Albrech ALT - adi geçen eser. 
örnek olarak alınmıs olan eski "Casuistique" bir nümune, ahdi tanzim edenler tarafindan böylece bozularak alınmış demektir. Yoksa "casuistique» nevide hukuk kaidesi daima șartl bir hüküm şeklindedir. On ve son cümiecikler birbirine bağlıdır. Hattâ bazan aym ayrı ehemmiyetteki halleri zikreden ön cümledeki cümlecikler bir birinden iki atıf edati ile ayırd edilir. Müellif misâl olarak Hurucun 21 inci babindeki 18 ve 19 üncü cümleieri göstermektedir : (31). Burada aslî ve tâbi cümlelerden mürekkep muntazam bir cümle yapısı vardı́r. Halbuki İsrail dilinde cümleler bir meratip gözetmeden gelişi güzel yan yana dizilebilir. Bu meratip silsilesi Israil için gụ̈ç anlaşılır bir șeydir. Aldığımı cümlede dokuz tâli cümlecik o sekilde bir araya konmuștur ki hepsi kendine düșen vazifeyi yerine getirmiștir. On cümleciklerde hadise sarih bir şekilde anlatilimıs, benzer hadiselerden ayırt edilmis nihayet son cümleciklerde hukuki netice bildirilmiștir.

Israil dilinin alışkın olmadığı böyle cümielerin menșei her halde dışarıdadır, ve bu dıșarı da ancak normal kazanın faaliyet sahası olabilir. On cümielerdeki unsurlar sorușturma için direktiffer mahiyetindedir. Son cümleier ise verilecek hüküm hususundaki direktifleri teșkil eder. Bu gibi cümleler tatbikat için hazırlanmıs hükürinireri ifade eder. Yani meslekten yetișmiş olmayan hakimlere (ihtiyar heyeiti gibi) muhakeme esnasında direktifler vermektedir. Bu neviden olan hükümlere hemen bütün yakın şark milletlerinin hukuklarında rastlanır. Nitekim ayni müellif «casuistique» şekilde kaleme alınmıs olan hükümler, tipik Israil düşünüs ve irade tarzına karși tamamen yabancıdır. Bı gibi hükümlerde Israil halk ruhu hiç ifadesini bulmamıștır. Bütün bu hükümlerde, tıpkı diğer eski şark hukuk kitaplarında olduğu gibi yalnız insan ile insan arasındaki münasebet hukukan tanzim edilmiștir, yani milli bağlıl:k veya diğer kavimlerden ayrilık gibi hususlar nazara alınmamıștır. Israil cemiyet hayatının mümeyyiz vasfı bütün haik nizamının Yahve'ye bağIt oluşu olduğu halde bu «Casuistique» hükümlerde böyle bir bağlilığın hiç bir alâmetine rastlanmaz.

Keza bu hukuk kaidelerinde Allaha atıf yapıldığı takdirde Yahve kelimesi geçmez. Allah veya ülühiyet tabirleri geçer. Bu itibarla Israilin «Casuistique» hukukunda tesadüf olunabilen dini unsurun pek zayif oluşundan bu nevi hukukun menşelerinin Israil dişı olduğu neticesine varılmaktadır. Bu hukuk layıktır ve bunun doğduğu cemiyette din ile hukuk arasındaki mesafe lsraildekinden çok daha büyüktür.» diyor.

(31) - Eğer adamlar niza ederken biri arkadasına tas vahut yumruk vurdukta c Simprerek vatağa dusserse kalkıp değnekle dışarda gezdiği takdirde onu vuran tebrive olunur ise de tatili müddetinin bedeli ile mualecesinin ücretini verecektir. 
Su halde bu cemiyet hangi cemiyettir? Albrech ALT, a göre bunu mümkün olduğu kadar yakında aramalıdır. Tâ Mezopotamya milletlerine veya küçük Asya milletlerine kadar gitmeye lüzum yoktur. Hattâ, keșfedilen eski kanunnameler muhteva itibarile Israil hukukuna benzese bile bunları Israilin « «Casuistique» hukukunun örneği diye kabul etmek için hiç bir ilmi sebep görülmemektedir. Kendi fikrince en yakın ihtimal șudur :

Israil millet haline geldiği vakit hukuk işleri için en tabii hoca, kendilerinden evvel Filistinde yerleșmis olan kimselerdir ki bunlara aralarındaki farklı unsurları ayırt etmeden «Kenaniler» denebilir. Göçebe bir hayat süren Israil oğulları Kenan iline yerleștikten sonra yerli bir hayatın icaplarını - hayata hakim olan fikir nizamlarile beraber benimsemek zorunda kalmıslardır. Su halde hiç olmazsa «Casuistique» hukuk hakkında Kenan hukuk nizamlarının iktibas edilmiş olduğu kabul edilebilir.

Böylece : bütün eski șark milletlerine has üslûp ve şeklin Filistinin Israil oğullarından evvelki sakinleri tarafından da kullanılmıs olması ihtimali «Casuistique» hukukun göçebe bir hayattan daha ileri yerleşmiş bir hayatın kültür seviyesindeki münasebetlere taalluk etmesi ve bu nevi hukuk kaidelerinin milli ve dini unsurlardan ârî bulunması gibi hususlar müellifi bu neticeye sevk etmiştir. Fakat Kenan hukukunun ne suretle iktibas edildiğini gösteren diğer harici vesikalar bulunmadığından ihtimaller sahasından yine çıkımış olmaz.

\section{2 - Kesin emirler șeklindeki hukuk kaideleri :}

Tevratta rastlanan emir şeklindeki hukuk kaideleri ve "Casuistique» kaidelerin sonradan bozulma sebepleri bize henüz Filistine yerleşmeden evvel göçebe bir halde dolașan Israil oğullarının kendi öz malları olan hukukun vasıflarını buldurabilir.

Böyle bir bozulmaya misal olarak Hurucun 21 inci babinin $22-25$ inci cümleleri gösterilebilir (32). Görülüyorki evvelâ hadisenin şartları sayılmış. ve zarar vaki olmadığı hal için hukuki müeyyide konmuş zararın vukuu halinde ise birdenbire uslup değişmiş ve sanki birine hitap edercesine cümle«kısas edeceksin!» seklinde bitmiștir. Keza bu kısas bendi basma kalıp bir formülü hatırlatmaktadırki bu kalıbın «eğer» seklindeki bir sart edatina zaten ihtiyaa yoktur. Bu formülün mense'i pek eskidir. «Yalnız şekil itibarile değil, muhteva itibarile de hükmün ön cümleciği ile son cümleceği arasında

(32) - Adamlar kavga ettikleri esnada bir hamile kadina vururtarda sikıt vaki olursa kadına bir zarar olmadığı surette ol kadının zevcinin takdir ettiği zamanı hakimlerin revi ile eda edecektir. Ve eğer zarar hasıl olursa cana can, göze göz, dişe diş ele el, ayağa ayak, yanığa yanık, yaraya yara, bereve bere kısas edeceksin.» 
bir uçurun vardır. Kısas formülünü buraya koyan kimse muhteva bakımından kasden bu ahenksizliği yaratmakla en mühim rolü oynamıstır. Eski «Casuistique» hüküm, ön cümlecikte baki kaldığı halde hukuki neticeyi ihtiva eden eski son cümlecik bertaraf edilmis ve bu eski cümleciğe hakim olan hukuk görüşü yerine ciddi ve amansız bir kısas prensibi kaim olmuştur. Demek oluyorki, ta köküne kadar birbirinden farklı olan hukuk görüşleri burada birbirile çarpışmış̦ır ve șayet «Casuistique» hukuk, menșe'i itibarile Kenan hukuku ise bu hukuku zorla kısas kalıbı ile bozan hukuku da, hilafi isbat edilinceye kadar tipik israil hukuku olarak kabul edebiliriz». Eski hukuk daha insaflı idi ve belki de filin sübjektif unsurlarını da nazara alıyordu. Halbuki bu gibi unsurlara kiymet vermek Israil hukukuna yabancidır. Daha sert ve kat'î olan israil hukuku yalnız filin dıs şekline bakar ve hemen kısas tatbik etmeyi kendi ruhuna daha uygun bulmuş olabilir.

$\mathrm{Oz}_{\mathrm{z}}$ Israil hukukuna aidiyeti tahmin edilen bu hukuk kaidelerine misal olarak gösterilen diğer kaideler umumiyetle üç grup altında toplanabilir:

a - Adam öldürme suçu : Hurucun 21 inci babinin 13 ve 14 üncü cümlelerinde bu bozulma vaziyeti büsbütün mütebariz bir haldedir. Uslup bir anda okuyucu şșııtacak kadar değişiverir: «herkim ki bir adamı darp edip öldürürse mutlaka katlolunacaktır ve lakin amden olmayıp eline Allah rast getirdi ise ilticası için sana bir mekân tayin edeceğim. Lâkin bir kimsenin komsusuna garazı olup onu hile ile öldürürse katlolunması için onu mezbahasından bile alacaksın»

Görülüyorki şartlı ön cümleciklerden sonra bir «sen» «ben» zamiri işe karışmakładır, ve suçun sübjektif unsurları baştan kale alındığı halde sonu (asıl metinde) ayni neticeye varmaktadır. Keza hükümde dini bir renk vardır ve Yahve kendi himayesine iltica etmesini emir etmektedir. Bu melce hakkı, amukaddes yerin masunyeti gibi ilahî bir fikri ifade etmektedir. «Yani ülûhiyetin himayesi içine alınmış olan kimse, işlediği fiilin hukukî tavsifi nazara alınmaksızın esas itibarile halkın kaza hakkından ebediyen sıyrılmış oluyor» bu bozulmalarda saf bir hukuk kaidesinin içine ilahî bir vaid, bir tavsiye de karısıyor. (33) cümlenin ilk kısmı yani «her kim ki bir adami darp edip ädürürse katlolunacaktır» parçası A. Alt'ın kanaatınca ibranî metinden çevrilirken değiștirilmiş ve «Casuistique» bir hale sokulmuștur. Halbuki asıl ibranî

(33) Tesniveden verilen misalde durum daha açktır: Tesnive 19: II «bir kimsenin kendi komsusuna adaveti olup onun ıçin pusuda oturur ve üzerine kalkarak onu vurur - dahi vefat ederse o adam bu sehirlerin birine firar ettiŏinde olvakit kendi sehirlerinin ihtivarları gönderip onu oradan celp ile velii demin eline teslim etsinler ve ölsün. Gözün ona merhamet etmesin, israilden suçsuz kan dökmek cürümünü def edesin ki sana havır geles 
metinde cümlenin bambaska bir bünyesi vardır. Burada, hem hadise, hem hukukî netice pek dar bir cümleye sıkıștırılmıștır. Oriiinalde bulunan beș kısa kelime çok ağır ve yüksek sesle okunmalıdır ki bunu dinleyen kimse her kelimenin manasını lâyıkile anlayabilsin. Halbuki üslubun bu kuvvetli icazi *Casuistique" tarza tamamen yabancıdır. Iște bu yeni üslup için müellif yeni bir tabir kullanarak «apodictique» üslup diyor. Bu «her kimki bir adamı öldürürse katlolunacaktır» cümlesinde kat'îlik ve sübjektif unsurları kale almamazlık yalnız sekil bakımından değil muhteva bakımından da vardır. Bu kesinliğin menşe"i her dökülen kan için amansız bir kefargt talep eden Yahve dir. Yahve'nin hükümleri serttir ve daima failin hayatını talep eder.

Onun hükümleri yerine getirilmediği takdirde bütün memleketin kudsiliği izale edilir ve milletinin varlığı tehlikeye maruz kalır. Bu da israil zihniyetinin bir hususiyetidir.

Kesin hükümlerin mevzuları umumiyetle ya milletin Tanrı ile olan müna. sebetlerinden mütevellit dini meselelere mütaalliktir yahutta insanların birbirbirile olan münasebetlerindeki mukaddes ve mahrem sahaya hususile aile münasebetlerine mütaalliktir. Bütün bu sahalarda Yahve'nin kayıtsız șartsız iradesine dayanıldığından bunun her ihlâli halinde ancak en ağır ceza verilebilir: failin șahsının imhası. (34) Meselâ : pederini veya validesini döğen

(34) - Will Durant'ın Yahve hakkındaki portresi kayde değer: \$Yahve, zaman zaman oburdur, doymak bilmez, kana susamıştır. Kabına sığmaz, renksizdir. Evilere karșı eyi, merhametlilere karșı mermahetli olacağım der. Vicdanı bir politikacı kadar lastiklidir. Gevezelikten hoslanır uzun nutuklardan keyflenir. Fakat çekingendir. Insanlara valnız arkasinı gösterir: Bu kadar beşer tabiatli Allah hiç bir zaman, hiç bir verde görül. memiștir.»

Keza Denis Saurat dinler tarihinde Yahve'den sōyle bahseder: kibraniler Filistine yerleştikten sonra Yahve kavminin kendisinden pek çok korktuğu bir Allah olmuștu. O kahhar bir. Allahtı ve onu gazebe getiren sevierin ne olduğu da pek ivi bilinemivordu. Insan Allahın zihninden geçen sevleri bildiŏini iddia edemezdi. Allaha karsı yapılan te. cavüzler daima cezasını bulurdu ve kativen unululmazdı. Ayni veçhile Allah, kendi kavmine yabancı kavimler tarafından yapılan tecavūzleri de cezasız bırakmazdı. Hattâ kendi kavmi haksız bile olsa bu yine böyle idi. Yabancıya karşi ahlâk yoktu. Yahve Misırdan çıarken ibranilere hırsızlik ve vağma dahi tavsive edebilivordu. Hurucun ücüncü babinin 21 ve 22 nci cümlelerinde : Misırdan çkarken kativen eliniz bos cıkmayacaksınız her kadın kendi komşusundan ve kendi evinde misafir bulunan kimselerden gümüs ve alıın tezyinat ve elbiseleri alacak, onları kız ve oğullarınıza geydirerek Mısırı soyacak. dırs Yahve kendi kavmini hiç bir zaman düşmana teslim etmez. Hattâ düşman haklı bile olsa. Fakat eğer israil Yahve've karsıı gelirse o zaman Yahve kavmini düșmana teslim eder. Ahd böyledir. Keza Yahve cocukları babalarının suçundan dolayı cezalan. dırır. Milleti kralın suçundan dolayi teczive eder: Kasdsızca işlenmiş olan suçları dahi cezalandırır ve Yahve oldukça haindir. Insanları hem günaha sevk eder hem cezalan. dirır..2 Histoire des Religions Paris 1933 Sh 184 - 191 
mutlaka katlolunacaktır (35) yahut «pederine veya validesine șetm eden mutlaka katlolunacaktır» (36) keza : «sihirbaz karıy sağ bırakmıya $\sin$ (37) ve «hayvana takarrüp eden kimse mutlaka katlolunacaktır» (38) hüküm!ıri bunun açık bir delildir.

b - Diğer taraftan öz israil hukukuna has başka bir hususiyet de maddi ve dünyevi müeyyidelerin yanı bașında ilahi ve dini müeyyidelerin bulunușudur. Bilhassa gizlice ișlenebilen ve beșeri kazanın uzanamayacağı sahalara taalluk eden suçlar bir (telin = lânetleme) cezasile karşılanır. Bu failin Israil ile Yahve'yi birbirine bağlayan hayat dairesinden aforoz edilmesi demektir. Telinlerin neticesini Yahve tahakkuk ettirir. Müminler toplanıp muayyen bir suçun failini telin eden sözleri dinledikten sonra bir (âmin) ile buna istirak eder ve kendisinin suçluyu tasvip etmediğini ondan ayrıldığını gösterir. Bu dinî hukuk metinleri tamamen Israilin malıdır: Misal olarak tesniyedeki 27 inci babin 12 - 26 ncı cümlelerindeki 12 düsturu gösterebiliriz:

1 - Oyulmus yahự dökülmüs puł yapıp gizlide nasbeden kimse melûn olsun ve bürün kavim cevaben amin desin

2 - Peder ve validesine şerm eden kimse melun olsun ve bütün kavim amin desin.

3 - Komşusunun hudut taşinı yerinden kaldıran melûn olsun ve bütün kavim amin desin.

4- Amayi yoldan saptiran melûn olsun ve bütün kavim amin desin ve yine ayni şekilde :

5 - Garip yetim veya dul karı hakkındaki hükmü tahrif eden,

6- Pederinin zevcesile yatan,

7 - Hayvanlardan birine takarrüp eden,

8 - Hemşiresile yatan,

9 - Kain validesiyle yatan,

10 - Komşusunu gizlice öldüren,

11 - Suçsuz adamı katl için rüşvet alan,

12 - Bu șeriatin sözlerini icrada kavi olmayan melûn olsun ve bütün kavim amin desin.

\footnotetext{
(35) - Huruc: 21; 15

(36) - Huruc: $21 ; 17$

(37) - Huruc: 22; 18

(38) - Huruc: 22; 19
} 
c - Levililer'in 18 inci babinin 7-17 cümleleri arasındaki 11 düsturun hepsi ibranice (lâ) edati ile başlayan birer kesin buyruk şeklindeki nehy'edici hükümlerdir. Bütün bu emirler yakın akraba arasında vaki olan veya gayri tabii tarzlarda olan cinsi münasebet suçlarının menine mütedairdir ve hükümlerin sonunda Israilden evvel yașamış ve bu gibi suçları ișledikleri için Yahve tarafından helâk edilmiş olan kavimlerin âkibetleri bir ibret dersi olarak gösterilmektedir. Evamiri așere de esas itibarile bu tip emirlerdendir. Bilhassa son dört halka tamamen bu şekildedir. (40) Bütün bu hükümlerde ahlakî cevher hukuki esaslardan daha mutebarizdir.

Yine A. Alt bu kesin hükümlerin israil dışı bir menșe'i olmadığını çünkü isráilin gelüp yerleștiği muhitteki kültür durumunun bu kesin hükümlere nazaran çok daha yüksek bir seviyede olduğunu kaydediyor. Diğer taraftan bu kesin buyrukların kökünü bir camiaya karșı verilmiş bir hitabede veya vaızda bulmak icap ediyor. Filhakika halkın bir araya toplanıp rahiplerin ağzından 'Yahve'nin hitaplarını dinlemeleri Israilde mutaddı. Yani, bu kesin buyruklar bir dinî merasimin sıklet merkezi oluyorlardı. Nitekim Tesniyenin yukarda zikrettiğimiz lânetleme emirlerini Israil rahiplerinin (Levililer) bir tepede toplanan halka okumaları, bu emirlerin başındaki cümlelerde emir edilmiștir. Bu sahnenin bir kereye mi mahsus olduğu, yoksa tekrarlanmasının mı mutad olduğu hususunda Tesniyenin 31 inci babının 9, 10,13 üncü cümlelerine (41) atıf yapan müellif ikinci ihtimalde karar kılmışır.

Burada zikri geçen haymeler bayramı Israile mahsusu birșeydir. Bu, haddizatında bütün mülkün, toprağın, Yahve'ye ait olduğunu zaman zaman Israil oğullarına hatırlatmak maksadını güder. Ahid hükümlerinin bu bayramlarda okunması da manidardir. Zirai senenin sonuna tesadüf eden bu bayramla artık yeni bir çalışma devresine geçilmek üzere eski devreden kalma bütün borçlar ibra, her türlü ihtilaflar tasfiye edilir. Bu yıl içinde artık Israil soyları Yahve'nin toprağından intifa edemezler. (41 a) Böylece İsrail halkı her altı yılda bir eski durumlarına rücu ve Yahve'yle olan Ahidlerini ihya ederler.

(40) - Bak: Yukarida not (20).

(41) - «Her vedinci senede ibra senesinde haymeler bayramında israilin kâffesi Allahın Rabbin huzurunda görünmek üzere intihap ettığs mahalie geldikleri zaman israilin kâffesi hazır ólup kulakları işidir iken bu seriati okuyccaksan. Kavmi yani erkek ile nisa ve cocukları ve sehirlerinde olan garibi cem evlevesin, taki işidip öğrenerek Allahınız Rabden hayf ve bu seriatin hep sözlerini hıfz ve icra edeler.

(41 a) - Teșrat: Lavililer: 25 ; 1 . Huruç : $23 ; 10$ ve devamı. 
Görüsslerini kısaca naklettiğimiz A. ALT, bütün bu tahlillerinin sonunda aşağıdaki neticeye varmaktadır:

«Kesin (Apodictique) hukuk hükümlerinin temeli İsrailin iptidaî devirlerindeki müesseselerde bulunur. Bu iribarla bu milletin iptidaî hususiyeti bilhassa bu çeșit hukuk hükümlerinden istihraç olunur. Fikrimizce bu hükümler, Devletten - önceki devrin mahsülüdür. Yahve dininin menşei çöl olduğu için, Yahve akidesine sıkı surette bağlı olan bu kesin hukuk hükümlerinin menșeini de çölde aramamız lâzımgelir. Bu suretle bu hukuk hükümlerinin merhametsiz karakieri kolayca anlaşılabilir ve ancak bu suretle bu çöl hukuku ile eski Kenan hukuku arasındaki fark izah edilebilir. Su halde Israilde yürürlükte bulunmuș olan bütün hukukun Musa zamanından Yahve ile israil oğulları arasında akdedilmis bir Ah'den ileri geidiặi hakkındaki akidevî görüs, hị̧ değilse kesin hukuk hükümleri hakkında doğru demektir.»

VII - ALT' In metodunun muvaffakiyer derecesi ve vardiğı neticelerin isabeti hakkında doğru bir hüküm verebilmek şüphesiz ki yetkili kimselere düsen bir iștir. Bizim bu hususda varabildiğimiz netice ise, hemen bütün rasyonalist müelliflerin Tevrattaki vahdetsizlik ve tecanüsden mahrumiyet hususunda ittifak efmis olmalarını müşahededen ibarettir. Kenan hukukuna yapılan atifla mesele yine tamamen aydınlanmıs olmamaktadır. Kenan eli gibi ceșitli kavimlerin gelip geçişine șahid olmuş ve çeșitli hakimiyetlerin türlü türlü hukukî tesirlerine maruz kalmıs olan bir mıntıkadaki hukuka atıf yapmakla yine sarih bir kanaata varılmıs olamaz. Zaten müellif de bunu kabul etmektedir. Bu incelemeler bize hakikatte tevrattaki hukuk görüslerinden hangilerini Israil oğullarının hakkiyle benimseyebileceklerini isaretle kalır. Yoksa yine açık ve itiraz götürmez bir hakikati tesbit etmiş olmaz.

Simdi ikinci safhaya geçmemiz gerekmektedir. Kenan hukuku demekle ne kasdedilmiștir? Tedkikimizin başında esasen israil hukukunu böyle tartıcı bir gözle tahlile sevkeden hadisenin ne olduğunu söylemiștik: Hamurabi kanunlarının keșfi. Bu keșif, Hukuk Tarihçileri âleminde o kadar müthiş bir heyecan uyandırmıștı ki o zamana kadar oriïinal bir eser sayılan Tevratın ve Israil hukukunun menşeinin artık keşfedilmiş olduğuna hükmedilmişti.

Simdi tetkikimizin ikinci kısmında bu meseleyi de incelemek suretiyle bu iki eski ve komşu hukuk sistemlerinin münasebet ve birbirlerine tesir dereceleri hakkında bugüne kadar varılmıs olan sonuçları gözden geçirmemiz gerekmektedir.

Kendisinden daha eski ve coğrafí mevki itibariyle kendisine pek yakın olan büyük bir medeniyet hukukundan Israil hukukun «tabiatiyle» müteessir olacağı yolundaki istidlal ve ihtimale dayanan kanaatların isabetsizlik 
derecesi meydana çıkınca tarihi araștırmalarda vesikalar tükenir tükenmez zekânın nasıl yanlış tahminler içinde bocaladığı bir kere daha sabit olmuştur.

\section{Ikinci Bölüm}

Hamurabi kanunları ile Tevrattaki hukukî hükümler arasındaki münasebetler meselesi

1 - Hamurabi kanunnamesi :

Milâdden evevl (2123 - 2081) yılları arasında yașamıs olan kral Hamurabi, bilindiği üzere birinci Babil hanedanının altıncı hükümdarıdır. Kırküç sene hükümdarlık etmiştir. Bugüne kadar edinilen bilgilere göre Babil İmparatorluğunun hakikî korucusu olan bu eneriik hükümdar zamanında bir çok galibiyetler kazanmış, ısyanları bastırmıs, imparatorluğun vahdetini ve düzenini tesis etmiş ve meşhur kanunları ile büyük bir mıntakada nizam ve asayişi sağlamıștır. Bu kanunlar $25 \times 2$ çapında diorit'den bir âbide üzerine hakkedilmiștir. Sonradan bu âbide milâdden evvel 1100 senesine doğru harp ganimeti olarak Sus şehrine nakledilmiștir. Iște 1901 - 1902 kısında Morgan'ın başkanlığı alıındaki heyet bu âbideyi parça parça bir halde Sus șehri harabeleri arasında bulmuștur. Âbide halen Louvre müzesindedir. Ảbidenin bir yanında kral Hamurabinin resmi vardır. Burada günes tanrısı olan Shamash kral Hamurabiye adı geçen kanunları bildirir. Böyece bu kanunlara ilâhî bir menşe gösterilmiş olur. Zaten ön sözde bu ilâhî menșe açıkca ifadesini bulmuștur. Burada Tanrının kral Hamurabiye bu kanunları kuvvetlilerin zaifleri ezmesine mani olmak, memleketini tenvir etmek ve halkın hayrını gütmek için verdiği söylenir. Mamafi bu başlıkła ifadesini bulan fikir kanunun muhtevasına hâkim değildir. Daha doğrusu Tevrat gibi tamamen ilahî bir kökten geldiği kabul edilen bir kanunlar mecmuasile bu âbidedeki hükümlerin layik ruhu arasında bir hayli fark vardır. Aynı hususiyete işaret eden Will Durant, ön sözdeki bu ileri ifadeyi bilhassa kendisini halkın hizmetinde telâkki eden bir hükümdarın pek modern görüșleri olarak kayd ettikten sonra şöyle der:«bilhassa tebarüz ettirdiğimiz kelimeler modern bir edâ tașımaktadır. Bu kelimelerin milâdden yirmibir yüz yıl evvel yaşamış bir sarkI müstebide izafesinde tereddüt edilir. Kendisinden altıbin yıl daha eski olan Sümer metinlerindeń mürekkep bir kanunlar mecmuasına başlık olarak nasıl olupda bu gibi sözlerin kullanılmış olduğuna hayret edilir. Bu menşein eskilik derecesi ve kanunların da Babilde isdar edilmis olması vakıası bu kanunnameye parçalı ve mütecanis olmayan bir mahiyet bahş eder. Kanun- 
name Tanrıları övmek ile başlar fakat bunu müteakip, bir hayli lâyık olan bu mevzuat artık ulûhiyete hiç bir atıfta bulunmaz. Kanunname bir kısım liberal hükümleri Barbarlara has kefaretlerle (cezalarla) hiç tefrik etmeden karıștırır, içinde bir taraftan iptidai kısas kanunu ile inceden inceye tanzim edilmis Ordal hükümleri bulunur, bir taraftan da kocanın tahakkümünü tahdide matuf gayet ince ve makûl hükümlere rastlanır. 285 metinden ibareł olan bu kanunname hemen ilmî denecek bir tarzda muhtelif kısımlara ayrilmıștır (42). ahıs hukuku, eşya hukuku, ticaret, aile tazminat ve iş gibi... bunların heyeti umumyiesi kendisinden bin sene daha genç olan Asur medeniyetinden daha ileri ve daha medeni bir kanunname teșkil eder. Birçok bakım-. lardan her hangi bir modern Avrupa devletinin kanunlarindan daha iyidir. Tarihte, Hamurabi kanunlarının hâtimesindeki șu sözler kadar güzel olan pek az söze rastlanır : «Hakîm kral Hamurabinin isdar ettiği ve sayelerinde memlekete sağlam bir temel ve hakșinas bir hükümet temin ettiği âdil kanunlar... ben koruyucu bir hükümdarim... ben Sümer ve Akad memleketleri halkını nefsimde topladım. Kendi hikmetimle onları (kanunlara itaata) icbar ettim, tâki kuvvetli arłık zaifi ezemesin ve dul ile yetimin hakkı tanınsın, her zulüm gören insan benim resmimin önüne tıpkı bir hakkâniyet kralının huzuruna çıkar gibi çıksın, âbidemin üzerindeki yazıları okusurı ve benim âbidem onun davasını aydınlatsın ve ona durumunu anlatsın, o da «Hamurabi, milleti için hakikî bir baba olan bir hükümdardır. Milletini sbediyen refaha kavușturmuștur ve memleketine hakka hürmet eden bir hïkümet vermişsir.» desin, tâki gelecek günlerde, istikbalde, memileketie hüküm :ürecek olan kral âbidemin üzerine hakkettirdiğin bu hakkâniyet söz! terine göre hareket etsin»... her ne kadar kanunnanıs tamamen lâyık bir görüșten ilham almıs isede Hamurabi, kendi otoritesini Tanriları: lasvibine mazhar ettirmek kıyasetini de göstermiștir. Zamanında istihkâmlar kadar mabedler de yaptırmıștır..) (43) görülüyorki ilahî bir menșe gösterilmesi daha ziyade siyasi bir dirayet neticesidir ve bu durum hemen bütün eski şark medeniyetlerinde görülen bir haldir.

Kanunnamenin muhtevasına gelince; belirli bir taksimata rastlanmadrğı hususunda hukukçular müttefiktir (44), Yukarıda da işaret ettiğimiz gibi muhtelif medeniyet seviyelerine has hükümler bazan insanı sassırfacak bir sira ile birbirini takip eder. Mamafi bu hayret vesileleri kanunun menşei hakkında bize önemli ip uçları verir. Äile hukuku denebilecek nisbetten müte-

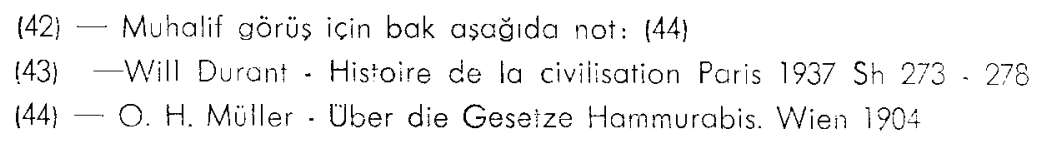


canis bir maddeler gurubu vardırki burada evlenme, miras ve evlâd edinme müesseseleri tanzim edilmiștir. Daha sonra gaiplerin karılarını boșama, ka$r ı$, cariye ve hasta kadının durumu, evlenme hediyeleri, evlenmeden evvellki borçlar, aile içindeki taarruz suçları, nişan bozulması ve nihayet miras hukuku gelir.

Kanunun 162 - 184 üncü paragraflarını teșkil eden miras hukukunda da şu hususlar tanzim edilmiștir: Karının ölümünden sonra miras, kocanın ölümünden sonra miras, kärı ve cariyenin miras hakları, miras hukukunda cihaz. Azadlı ve toprağa bağlı olan bir kölenin çocukları için tesbit edilmiș olan miras hükümleri, dul karı ile çocuklar arasındaki münaseber, kızların miras hakları. Daha sonra evlâd edinme hakkındaki hükümler $\$ \S(185$ - 193). $\S \S(127$ - 193) de bu nisbeten insicamlı mevzuatın baș tarafında vediaye mütedair ( $\$ \$ 120$ - 126) hükümler vardır. Keza yine bu insicamlı kısmın sonunu da kısas hakkındaki hükümler takip eder : ( $\$ \$ 194$ - 216). Kanunun bașındaki ilk bes paragraf tabir caizse muhakeme usulüne mütealliktir. Sanik, tanık ve yargıç hakkında bazı hükümleri ihtiva eder. Müteakip paragraflarda sık sık ișlenen isuçlar zikir edilir. Alelâde hırsızlık (\$\$ 9 - 13) adam kaldırma ( $\$ 114-20$ ) kapalı yerde hırsızlık ve zabt ( $\$ \S 21$ - 24) yangın esnasında hırsızlık (§§ 25). Bu hükümler de sistematik bir şekilde bir birine bağlı sayılır.

Daha sonra ziraî hükümler gelir : Feodal emlâkin kirası ( $\$ \S 26-41$ ) tarla hasılat icarı ( $\$ \S 41$ - 47), henüz toplanmamış olan mahsullerin rehnedilmesi ( $\$ \S 48$ - 52) ve nihayet sel yüzünden doğan zararlar, mera suçlarına müteallik hükümler, orman suçları ve ev kirası gibi müesseseler de bir vahdeł teşkil eder. Fakat bundan sonra gelen haciz, tazyik hapsi, rehin olarak verilen şahıslar ve vedia gibi müesseseler ne daha evvelki ne de daha sonraki mevzulara uymaktadır. Kanunun son kısmında da àynı ahenksizliğe ișaret eden Heinrich MULLER hülâsaten aşağıdaki neticeye varmıștır: "Shamașh tanrısının bu kanunu büyük kral Hamurabiye böyle sistemsiz bir tarzda dikte ettirmiş olması ihtimali akla uygun gelmez. Bilakis bu kanunun büyük bir hukukcu tarafından kaleme alınmıs veya daha ziyade tedvin edilmiş olduğuna hüküm edilebilir. Kanunda müşahade edilen zahirî sistemsizliğin hikmetini anlamak için kanun koyucuya hâkim olan fikir silsilesini incelememiz lầzımdır. Baştaki usule mütedair hükümlerden sarfınazar edilirse iki husụs müşahade edilebilịr: evvelâ ceza hukuku ile medeni hukuk arașında bị karışma vardır. Sonra iptidai hukuk kaidelerile (compliqué=karmașı) hukụk kaideleri birbirile içiçe girmiş vaziyettedir. Hiç kimse, hırsızlık, gasp, mera suçları gibi mevzulara mütedair kanunların bir taraftan ceza mahiyetinde olduğunu diğer taraftan da en iptidai münasebetlere tekabül ettiğini inkâr edemez. Ayni veçhile feodal çiftliklerin saray veya devlet tarafından yüksęk 
rütbeli askerlere iare edilmesinin Kommenta yani Acenta ve seyyar ticaret memurlarının tavassutu ile akdedilmiş olan toptan ticaret mukavelelerine müteallik hükümlerin terakki etmiş ve çok yüksek bir seviyeye kadar yükselmiş olan siyasi ve içtimaî bir durumu ifade edeceğini de herkes kabul eder. Acaba zikri geçen hususlardan kanunun oriiinal șekli için bir ipucu bulmak mümkün olmaz mı? Ayni müşahade kanunun son kısmı hakkında da variddir. Kısas, hayvan kirası, huysuz öküz, çoban gibi müesseseler yanında hekim, gemi inşası ve tarife meselelerine de tesadüf olunmaktadır ki zikri geçen son müesseseler müterakki bir içtimaî durumu ve nizam içindeki bir devletin vücudunu istilzam ederler. Aile hukukunun ince bir tetkiki sırasında da aynı müșahade yapılabilir. İște bu mülâhazalardan çıkartığımız netice şudur : bu kanun muayyen ve sabit normlan ihtiva eden eski iptidai bir hukuktan doğmus ve tekâmül etmiştir.. ohalde sözlü olarak intikal etmis bir hukuk veya yazılı olarak tesbił edilmis iptidai bir hukuk sisteminin vücüdü kabul edilirse ozaman, tedvin eden kimsenin eski ananede kolayca terk edemediği bir modele sahip bulunduğu kolayca anlaşılabilir. Diğer taraftan saray mensuplarindan kölelere kadar inen bir içtimai meratip silsilesi kanunun bütün ruhuna hakimdir. Mamafi Hamurabi Kanunu keșfedilmiş ise de buna modellik ettiği tahmin edilen iptidai hukuk meselesi ancak bir ipotezden başka birşey değildir ve henüz keşfe muhtaç bulunmaktadır.»

Su halde bu kanunname o zamana kadar mevcut olan hukuku (işter örf ve adet şeklinde ister iptidai bir metin halinde olsun) ıslah maksadını güden bir tedvin eseridir. Fakat sadece bir tedvinden de ibaret sayllamaz. Eski sarkła bugüne kadar bundan daha mükemmel bir kanunnameye rastlan-

mamıstır. (45) Hattâ kanunnamenin zamanına nisbetle pek ileri olușu, bazı hukuk tarihcilerini bunun tatbik kabiliyetinden șüpheye düşürmüs ve kanunname ile hem zaman olan tatbikat ile ilgili hukukî vesikalarla arada hayli farklar olduğuna işaret edilmiştir. Bu fikre göre Hamurabi kanunları bir nevi tedvin modeli olarak yapılmıs ve bugünkü tabirile kâğıdda kalmıştır. Tatbikatta bu hükümlerin yürüdüğüne mütedair hiç bir vesikaya rastlanmamıștır. "Oyle görünüyorki kralın büyük eseri ancak bir tasavvur şeklinde

kalmıs've hiç bir zaman gerçek hukuk mahiyetini almamıştrr.» (46) Bu hususta bir kıymet hükmü vermek için kanaatimizce acele etmemek gerekir. Bugüne kadar çıkan hukukî vesikalara dayanarak verilecek bir hüküm ancak muvakkat bir değeri haizdir. Yarın kanunun vaktile tatbik edilmiş olduğuna mu-

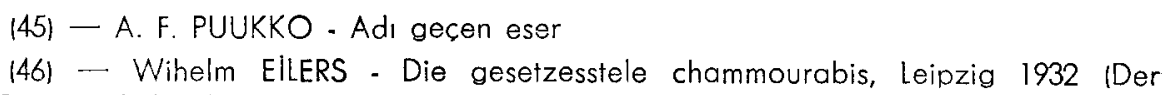


Tedair vesikalar bulmayacağımızı kim temin eder? Diğer taraftan bu kadar teferruatlı meseleleri inceden inceye tedvin etmiş olan 40 asır evvelki bir kanunnamenin tamamen tatbik edilip edilmediğini tesbit de imkânsız denecek kadar zordur. Nihayet ele alınmış olan, halline uğraşılmış olan meselelerin işaret ettiği medeniyet seviyesi nazara alınırsa kanunnamenin kısmen de olsa o zaman için hayli karmaşık sayılacak işleri halle uğraștığı düșünülebilir ve tatbikattaki - bugün için meçhul olan - muvaffakiyet derecesinden sarfinazar edilerek bizzat kanunnamenin yine muayyen bir seviyedeki hukuk fikrinin ifadesi olduğu tereddütsüzce kabul edilebilir. Ve bu seviye, kendisile çağdaş ve hattâ kendisinden çok genç olan diğer hukuk sistemlerine hâkim fikir seviyesinden așikâr șekilde yükseiktir.

II - Menşe meselesi ve bu bakımdan Tevrat ile olan münasebeti :

Hamurabi kanunlarının daha eski Süıner mevzuatına dayandığı ancak bazi hususlarda isbat edilebilmiştir. Daha başka hangi kaynaklardan istifa-

de edildiği henüz bilinmemektedir. (47 a) Menșe meselesini gerek Tevrał ve gerek Hamurabi kanunları için müștereken tetkik zarureti vardır. Zira zaman itibarile Tevrat yenidir ve Israil oğullarının uzun müddet sakin oldukları Kenan ilinde yine uzun zamanlar Babil hukukunun tesirleri hâkim olmuștur. $O$ halde Israililerin Kenandan müteessir olduğu kabul edilince bunun Babil hukukundan müreessir olduğu manasına gelip gelmediği düşünülebilir. Nitekim Kautzsch bu faraziyeyi müdafaa etmiștir: «bütün imkânlar içinde en büyük ihtimali haiz olan șudur ki Hamurabi kanunu, Kenanlilarda milâdden evvel XV - XIV inci yüz yılların dönüm noktasında müessir olmuștu ve Kenanlılar kanalı ile de ihtiyaçların icabı nisbetinde Israillere intikal etmiș, onlar tara-

findan benimsenmistis (47 b) Fakat burada mesele Hamurabi kanunlarına kadar geri götürülmekle halledilmiş olmaz. Zira bu kanunun da bir vahdet ve tecanüs arz etmediği, tıpkı Tevrat gibi muhtelif seviyedeki hukuk anane ve görüșlerinin bir mecmuası olduğu sabittir. Suhalde bunu da ayırmak lâzımdır. Hangi kısımlar Babil medeniyetinin mahsulüdür, hangileri daha başka ve daha eski bir kökten alınmıştır ve nihayet bu kök Babil kanununa ihtiyaç olmadan doğrudan doğruya Tevrata müessir olnıus bir kök olamaz mı? Daha doğrusu gerek Tevrat gerek Hamurabi kanunu birbirlerinden mustakil olarak müșterek bir kökten ilham almış olamazlar mı? Yoksa her ikisinin de örnek aldıkları eski hukuk sistemleri başka bașka sistemler midir? Suhalde simdiye kadar ortaya atılan fikirleri üç gurup altında toplayabiliriz :

(47 a) - Wilheim EilERS - Adi geçen eser.

(47 b) - D. H: MULLEK'den naklen (Semitica. II: Heft: Wien: 1906 
A - Tevrai (hususile Bundesbuch) doğrudan doğruya Hamurabi kanunưndan alınmıştır.

B - Tevrat doğrudan doğruya Hamurabi kanunundan alınmış değildir. Fakat Hamuraki kanununa örneklik etmiş, çekirdek vazifesini görmüs olan daha iptidai müşterek bir metinden alınmış ve işlenmiștir.

C - Her iki kanun mecmuası da birbirinden ilgisiz bașka bașka örneklérden istifade etmis ve zamanın icaparına göre ilâveler ve tadillerle kendi. hüviyetierini kazanmışlardır .

A - Tevrattaki hükümlerin doğrudan doğruya Hamurabi kanunundan alındığını iddia edenler arasında Obbink - Brouwev, H. Gressmann, Anton Jirku sayılabilir. (48) Bunlardan üçüncü müellifin fikirlerini etüdümüzün birinci bઢ̆lümünde «mukayese metodile varılan neticeler» kısmında göstermiş ve sırf harici benzerliklerden töyle bir net'ce çıkarmanın, ne dereceye kadar isabetli olacağını da tayin etmiștik.

B - Hamurabi kanunnamesi ile Tevratin birbirlerile olan benzerliklerini izah için ikinci görüs tarzı, bunların birbirlerinden müstakil olarak müsstérek bir kaynaktan faydalanmıs olmaları fikridir. Iptidai bir metin veya örfüadet hukuku h\&m Hamurabi kanunnamesinin çekirdeğini teşkil etmiş hem de Tevratta ifadesini bulmuş olabilir. Bu fikri müdafa edenler arasında viyanálı Semitist Profesör David Heinrich Müller vardır. Mütaaddit defalar fikirlérine temas ettiğimiz bu zat 1904 de, yani Hamurabi kanunnamesinin keșfinden hemen sonra verdiği bir konferansta ilk anda kendisinin de bu kanunnamènin Tevratin örneğini teșkil ettiği zehabine kapıldığını kaydettikten sonra derhal kanaatini tashih ettiğini ve neticede Tevratin, doğrudan doğruya Hamurabi kanunlarından değil, fakat ihtimalki Hamurabi kanununa örnek ve çekirdek vazifesini görmüs olan başka bir metinden veya örfüadet hukukundan müihem olduğu kanaatine vardığını söyler. 1906 da münteșir bir etüdünde şöle der: (49) «Arché - Type meselesi için Tevratın nasıl meydana gelmis olduğu değil, Musanın Hamurabi kanununu kaynak olarak kullanıp kullanmadığı hususu ehemmiyetlidir. Daha doğrusu Musa, Hamurabi kanunundanmı, yoksa Hamurabi tarafından kullanılmıs olan başka bir kanundan mı ilham almışır? Cünkü Musanın Hamurabi kanunundan mülhem olmus

(48) - A: Jirku - Altorientalischer Kommentar zum Alten Testament. 1923 Sh: $91 \mathrm{H}$. Gressmann - Die alteste Geschichtsschreibung und Propheten Israels: 211 OBBIK BROUWER - Inleiding tot den bijbel, Sh: 225

(49) - D. H. MOLLER - Semitica: H: Heft: Wien: 1906 (Sitzungberichte der Kaiserlichen Akademie in Wien Philosopnisch-Historiche Klasse. Band: CLIV Sh 61 . 87 
olması hakkında ileri sürülen büłün noktalar veya sebepler yine Muscinın Biżżat Hamurabinin iktibas ettiği bir kanundan mülhem olmuş rlması hakkinda da ileri sürülebilir. Bu itibarla Kautzch'un faraziyesi it $t$ ecilmelidir. (50) Milâddan evvel XV inci yüzyılda Babil ile Misır ve Filistin arasında muvasala mevcut iken Hamurabi kanunu veya bu kanunia karabeti olan bașka bir Arché-Type ne gibi sebeplerden dolayı daha evvel garp memleketlerine gelmiş olmasın? Meselấ Amarna mektupları vardır ki Hamurabi kanưnu ile hem ahenk olan Hüruç babinin şümülünü aşmakładırlar. Ne gibi sebeplerden dolayı Avram buna benzer bir levhayı veya birçok daha küçük levhalari yanında alıkoymus olmasın?»

Müellifi 1904 de verildiği konferansta böyle bir müșterek bir kaynak fikrine meyil ettiren sebeplere gelince; burada iki hususu tefrik lâzımdır:

a - Musa kanunlarile Hamurabi kanunnamesi arasındaki așikâr benzerlik noktaları.

b - Musa kanunlarının Hamurabi kanunnamesindeki hükümlere nazarán seviye itibarile yine aşikâr geriliği.

Benzerlikler hakkındaki fikirlerì «mukayese metodile varılan neticeler» kısmında incelemiștik. Yani sadece benzerliklerin vücudundan netice istihracine kalkmak hatalı olur. Musa kanunlarındaki gerilik ise, bunların kendilerinden daha mütekâmil bir kanunu örnek almamış olmalarına delildir. Şuhalde Tevrat hükümleri Hamurabi kanunlarını değil, fakat bu kanunlara müessir olmus olan daha iptidai bir kanunu örnek almış oimalıdır. Böylelikle hem bu iki kanun arasındaki benzerlik, hem de daha iptidai olan Musa kanunlarının daha mütekâmil olan Hamurabiden mülhem olamıyacağı keyfiyeti kolayca izah edilir. Şimdi ikinci hususu müellif şöyle izah etmektedir:

«Filhakika ben de aylarca Hamurabi kanunu ile meşgul olduktan sonra Musa kanunlarının da doğrudan doğruya veya dolayısiyle olsun en sonunda yine bu kanunlara irca edilmesi gerektiğini zan efmiștim. Fakat Hamurabi kánùnlarinin ruhuna nüfuz ettikçe bu fikrin tamamen imkânsız olduğunu gördüm. Zira:

1 - Muayyen karmaşık münasebetlere uydurulmuş ve yine Compliqué hukuk münasebetlerini gösteren bir kanun Codexi, basit ve iptidai münasebetlere pek uygun düșen bir kanuna menbalik efmiş olamaz. Hiç kimse böyle karmașik bir eserden bu karmașıklığın (complication) un izlerini hiç belli etmeksizin sırf temel káideleri istihrac edemez. Bazı misaller bu fikrimi canlandirmaktadır.

(50) - D. H: MULLER den naklen Bak: yukarda bölüm: III 
Musa kanunlarında bulunan hırsızlık hakkındaki basit hükümlere mukabil, Hamurabi kanununda buna tam yedi paragraf tahsis edilmiştir. Mabed ve saraydan çalınmıs malların istihkakı hakkında basit usül ile, alelâde bir ferdin gaip ettiği șeyin istihkakına mütaallik pek karmașık muhakeme usulü iptidai mahiyeite olamaz. Böyle bir mevzuda saray ve mahkeme hukukcularının iștiraki kabul edilmelidir ki bunlar uzun bir tatbikat neticesinde dünyanın en basit işini bu kadar karmaşık bir hale sokmus olsunlar. Keza buna benzer mülâhazalar kısas prensibi hakkında da variddir: Musa kanununda bu prensip şu sekilde ifade edilir: Cana can, göze göz, dişe diş, ele el ayağa ayak. Basitliği ve takip ettiği sıradaki tabiilik itibarile bu cümle en iptidai kanunların damgasını taşır. Fakat Hamurabi kanununda bu temel prerısip 196 - 201 paragraflar arasında tafsilâtlı bir șekilde izah edilmiștir :

(\$ 196 da hür bir adamın gözünü çıkaranın gözü çıkarılacağı, ve $\$ 197$ de kemiğini kıranın kemiği kırılacağı bildirildiği halde müłeakip 198 de bir kölenin «mașenkak» gözünü çıkaranın bir mine'lik bir para ödemekle kalacağı bildirilir. Keza $\$ 199$ da bir esirin gözünü çıkaran veya kemiğini kıranın, onun sahibine esir bedelinin yarısını ödemekle yetineceği bildiriliyor. Aynı veçhile $\$ 200$ de bir adam kendi sınıfından olan bir kimsenin dişini kırdığı takdirde onun da dișinin kırılacağı bildirildiği halde 201 de diși kırılan köle olduğu takdirde 1/3 minelik para verilmekle yetineceği bildiritiyor.)

Burada muhtelif sınıfları nazara alarak tefriklerde bulunmak ve tabii silsileyi değiștirmek mecburiyetinde kalan Hamurabi kanununun, Musa kanunu için bir kaynak teșkil etmemiş olduğunu herkes derhal teslim eder.

Hatîa Musanın Hamurabi kanunundan iktibaslarda bulunmadığı hususunda tabir caizse riyazî bir delil de gösterebilirim :

Hamurabi kanununun 250 nci paragrafında sokakta bir insanı süsen öküz sahibine karşı tazminat iddiası ileri sürülemez. Fakat hayvan huysuz olarak tanınır ve sahibi kendisine ihtar edildiği halde hayvanına mukayyed olmamış olursa süsme halinde muayyen bir para cezası vermekle mükellef tutulur $\S 251$. Haibuki Musa kanununa göre daha ilk halde hayvan öldürülmektedir. Yani hayvan sahibi hayvanının kıymeti kadar bir zarar görmektedir. Ikinci halde hayvan değil sahibi de öldürülmektedir. Meğerki öküzden zarar gören kimsenin rizası ile bir diyyet ile kurtulmus olsun. Bu hükümler arasındaki benzeyiş ve farklar okadar hayrete değmezse de Musa hukukunda mevcut olan küçük bir ek büyük bir ehemmiyeti haizdir: «öküz bir erkek çocuğunu veya kız çocuğunu süserek öldürürse ayni hüküm tatbik olunur.» Bu hal Musa kanununda suçun objelerinin çocuk olmaları halinde de öküz sahibinin cezaya çarpılacağı hakkında yegâne hükümdür. Kanun vazı bu 
ilâvede âdet veya kanun olarak yaşamış olan bir şeyi red etmek istiyor. Fakat neyi?...

Hamurabi kanununda babanın suçundan onun oğlu veya kızının öldürüldüğü üç hal vardır: 116,210,230. Bunlardan $\S 116$ da, alacaklının evine rehine olarak gönderilmiş olan borçlunun oğlunun bu evde dayak ve mahrumiyet yüzünden ölmesi halinde, alacaklının oğlunun öldürüleceği yazılıdır. Görülüyor ki ölüme sebebiyet veren bizzat alacaklı olduğu halde cezayı onun oğlu çekmektedir.

Keza $\$ 210$ da bir bașkasının hamile olan kızını dayakla öldürenin, kendisi değil kızı öldürülür. Nihayet 230 da mimarın hatası yüzünden cürük yapılmıs olan bir ev yıkılıpda içinde evsahibinin oğlu ölürse, mimar değil, mimarın oğlu ö!dürülür. Oküzün süsmesi halinde ise Hamurabi kanunu zaten daha hafiftir ve zaten huysuz öküzün hareketlerinden dolayı sahibi ölüm cezasına çarpılmaz... O halde Musa kanunu, bu ek ile Hamurabi kanunundaki durumu değil, belki ondan daha iptidai, daha eski bir kanundaki durumu (yani öküzün, bir çocuğu süsmesi halinde öküz sahibinin değil, onun çocuğunun öldürülmesini kabul eden bir kanunu) ıslah etmek istemiștir. Zira Musa kanunlarına hakim olan ıslah ruhu: anaların ve babaların çocukları yüzünden, keza çocukların anaları babaları yüzünden öldürülmemeleri esasıdır... Şimdiye kadar söylediklerimizi hülasa edersek bir taraftan her iki kanunun pek sıkı bir surețe birbirine bağlı bulunduğu, diğer taraftan da birinin diğerinden iktibas edilmiş olamayacağı neticesine varırız. Her ikisinin de birbirinden müstakil olarak eski bir örfüadet hukukundan ileri gelmiş olması ise hemen imkânsızdır. Sekil itibarile benzerlik ve sıra itibarile ayniyet edebî bir karabetin inkâr edilmez alâmetleridir. Bu dilemden ancak bir tek yol ile kurtunulabilir: $O$ da kaleme alınmış olan bir kanun faraziyesi veya daha ziyade her iki tedvinin kaynağını teşkil etmiş olan Arché-Typ'in mevcudiyeti. "Bu faraziye kabul edildiği takdirde Hamurabi kanunlarındaki sistemsizliğin izahi kabil olacağını ve araya giren yeniliklerin ve daha medeni bir cemiyete has hükümlerin eski modeli zamana uydurmaya çalışan tedvin hareketine atfedileceğini ilâve eden D. H. Müller, gerek Tevrata ve gerek Hamurabi kanununa örneklik ettiğini farz ettiği bu meçhul iptidai kanunun ruhunu şöyle tavsif eder :

1 - Kan davasının yerine kısasın kaim olușu. Yani tehevvürle veya daha fenası soğukkanlılıkla yapılan intikam yerine daha adil olan mukabeleibilmisi esasının kaim olușu.

2 - Yalnız kötü filin değil, ayni zamanda bu kötü file munkalip olacak kötü niyetin de cezalandırılışı: Yalan yere șehadette olduğu gibi: bir kimse :mahkeme huzurunda bilerek yalan yere ședahet ederse ve neticede diğer 
bir kimsenin cismani veya mali bir zararna sebep olmak ihtimali varsa sahidin yalancılığı hükmün infazından evvel tesbit edildiği takdirde suçlunun giyeceği cezayı şahid giyer. Hamurabi kanunu $\S 3,4$

3 - Bir suç için ancak bir ceza verilir. Yani idam cezasının yanında cismani tazyik ve para cezası da verilemez.

4 - Kısas prensibi mali mahiyette olan suçlar hakkında da tatbik olunur... Tahrip edilen şeyin değerinin iki veya beş misli olarak takdir olunur.

Netice itibarile müellif her iki kanunu henüz (1904 de) keșfedilmemiş olan daha iptidai bir örnek - kanun tipine rapt etmekte fakat Tevratin doğrudan doğruya Hamurabi kanunu örnek tutmadığını da belirtmekłedir.

C - Uçüncü fikri müdafaa eden Hollandalı bilgin M. David 1939 nisanında verdiği «Hamurabi kanunu ve bunun Huruçdaki hukuk kaidelerile olan münasebeti» (51) adlı konferansında her iki kanun arasında ne doğrudan doğruya ne de dolayısiyle hiçbir münasebet olmadığı neticesine varmıştır. Zaten buraya kadar anlattığımız fikirlerde doğrudan doğruya olan münasebetin müttefikan red edildiğini görmüștük. Üçüncü fikrin yeniliği ise müsterek ve eski bir örnek - kanun meselesini red etmesidir. Müellifi bu hususta ısrara sevk eden âmiller her iki kanun arasındaki birbirine ircai imkânsız ayrlıklar, farkllıklardır. llk bakışta benzerliklere dayanarak hükümler çıkartan farihçilerin yanıldıklarını iddia eden müellif bilhassa Babil ve Israil cemiyetleri arasındaki farklara temas ełmektedir. Bu iki cemiyet birbirlerinden bünye ve seviye itibariyle okadar uzak, okadar farklidırlarki bunları tanzim eden kanunların birbirlerinden alındığı veya ayni kökten gelme oldukları tasavvur bile edilemez. Müellif, bilhassa karunların sosyal hayatın bir mahsulü olduğunu ve birbirinden bu derece farklı cemiyetlerin birbirlerine benzer mahsuller vermiyecekleri tezini müdafaa etmekiedir. Vakaa șimdiye kadar naklettiğimiz fikirlerde de bu sosyal farklara temas edilmiş, Israil cemiyetinin daha geri, Babil cemiyetinin daha ileri olduğu tebarüz ettirilmisți. Fakat M. David'in issaret ettiği farklar sadece bir medeniyet derecesi farkı olmaktan uzaktır. Bu iki cemiyetin bünyesi birbirinden o derece farklıdır ki bu ayrilık sadece bir tekâmül farkile izah edilemez. Bu farklılikları birkaç bendde toplayabilirsek durum iyice açıklanmış olur:

1 - Içtimai sınıflar

Babilde muhtelif milletler ayni siyasi birliğe dahil olarak uzun zamandanberi sakin bulundukları topraklarda yașamakta idi. Sınıflar teessüs et-

151) - M. DAVID - de Codex Hammurabi en ziin verhouding tot de Wetsbepalingen in Exodus (Tiidschrift voar Rechtsgeschiedenis) den ayr bası. 13 . Nisan - 1939 do Leiden'de verilmiş konferans. 
mịs ve crada bir meratip silsilesi kuruinusștu. Sınıf ayırdı yalnız hür-köle yahüt yerli-yabancı gibi basit bir taksim üzerine yapılmıyordu, bilhassa mesleki farklar üzerine müessesti: Arazi sahipleri, füccarlar, memurlar, esnaf gibi. Buna mukabil yerli ve yabancı tasnifi yoktu. İsraillerde ise - ruhban stnıfı hariç - böyle bir ayırda rasłlanmaz. İsrail oğulları ancak bașka ırklardan tefrik edilir yoksa kendi aralarında bir sınıflaşma yokłur. Babilde mevcut olmayan vatandas - yabaneı ayırdı ise İsrailde kuvvetlidir. Hattâ yabancılar arasında dahi muhtelif farklar gözetilmiștir: Nokri denen zümre hususi bir himayeden istifade etmez ancak misafirperverlik ile karşılanır. Buna mukabil Ger denen zümre cemiyet içine kabul edilmiștir ve muayyen bir himayeye mazhardır. Hülâsa Babil cemiyeti kozmopolit bir cemiyettir ve burada servet ve meslek farkına dayanan bir sınıflaşma vardır. Israil cemiyeti ise kuvvetli bir șekilde millidir.

\section{2 - Íktisadi durum}

a - Ticaret: Babilde ticaret bir hayli inkişaf etmiş ve oldukça karmasık ticari münasebetler hüküm altına alınmıştı. Ticaret ortaklıkları ve büyük tacirler, toptancılık ve millełler arası ticaret safhasına kadar gelmişlerdi. Eski Babilden kalma birçok mukavelenameler ve ticari mektuplar bu cemiyette ticaretin nasıl bir yer futtuğunu iyice belirtir. Esasen bu hal, kanunun tüccarlara tahsis edilen maddelerinin çokluğundan da istihrac edilebilir.

Buna mukabil Israilin bașlangıçta hiç de tüccar bir millet olmadığı malûmdur. Israil oğulları Babil esaretine kadar asıl manada ticaretle hemen hiç meşgul değildiler. Bu işleri gezgin Mısır tacirleri yapardı. Sahil mıntakalarındaki ticaret Fenikelilerin elinde idi. Dahildeki ticaret işlerile de yerli Kenanlılar meşguldü. Zaten bu durum Tevrattan da istihraç edilebilir, asıl manadaki ticaret hakkında yanlış ölçü kullanmanın meninden bașka hiçbir hüküm yoktur: Borcun ancak zaruret halinde alınacağı zihniyeti hâkimdir. Kredi ile büyük ticari münasebetlere girișilebileceği hiç düşünülmemiștir. Borç için bahis konusu olan rehin mevzularının ehemmiyetsizliği borç almanın nasıl bir fakruzaruret haline hasredildiğini büsbütün tebarüz ettirir: Elbise, değirmen tașı, el değirmenleri (Huruç: 22, 26 «Eğer komşunun elbisesini rehin olarak alırsan onu günes batmazdan evvel kendisine geri veresin. Zira o, onun tek elbisesidir..» Tesniye 24,6: «Kir kimse değirmeni yahud üst taşını rehin almasın, zira hayatı rehin almış olur.) Bundan başka her yedi sene sonundaki umumi ibra mecburiyetinin uzun vadeli mali uzlașmaları imkânsız kılacağı hiç nazara alınmamıştır. Demekki Israil cemiyeti bu gibi uzlaşmaIarın yabancısı idi.

b - Ziraat: Babilde ziraat umumiyetle büyük ișletmeler tarafından yapılırdı. Hükümdara ve mabedlere ait geniş tarlalar vardı ki bunlar işçiler 
veya kölelere işlettirilirdi. Böyle yapılmadığı zamanlar. köylülere hasılat ica$\mathrm{r}$ ile verilirdi. Babile ait vesikalarda bu gibi icar mukavelelerine sık sık rastlanır.

Israil hukukunda ise buna benzer hükümiere rastlanmaz. Zaten (Eșsiya: $5,8)$ büyük çapta toprak sahibi olmak bir haksızlik sayilır ve imkân nisbetinde önlenmesi gereken bir haldir. Tarlalar sahipleri ve sahiplerinin aileleri tarafından işlenir.

Böylece bu farklı iktisadî durumlar, mamelek hukukuna mütaallik kaidelerde her iki kanun arasında büyük farklara sebebiyet vermiştir.

$c$ - Köleler : Babilde büyük çaptaki zirai faaliyet köle kullanılmasin. zaruri kılmışır. Köle bir çalışma âleti olarak ele alınır. Köleye ika edilen cismani zararlar onun çalısma kabiliyetini azaltacağı cihetle sahibine kar\$̧ı yapılmış bir mali zarar telâkki edilir ve bu bakımdan tazminatı doğururdu. Filhakika $\& 116$ da borç için rehine olarak verilen ve eziyetle ölen kimsenin hür bir adamın kölesi olması halinde failin, köle sahibine $1 / 3$ mine para ödeyeceği yazılıdır. \& 199 da esirin gözünü çıkaranın, efendisine esir bedelinin yarııını ödeyeceği bildirilir. $\$ 213$ de hizmetçi kızın çocuğını düşüren kimsenin, sahibine 2 șekel para tediyesi ile mükellef olduğu, keza $§ 214$ de hizmetçi kızın bizzat ölmesi halinde ise gene onun sahibine $1 / 3$ mine para ödenmesi gerektiği bildirilmektedir. Halbuki bu gibi zararların hür adamlara işlenmesinde durum ne kadar farklıdır! Köle ile bir eşya, bir istih. sal vasitası arasında hiçbir fark yoktur, telâfisi düşünülen șey, sadece efendinin bu yüzden uğradığı zarardır. Bu telâkkinin neticesi olarak köleler sürü halinde hariçten memleket pazarlarına idhal edilir, alınıp satıllir. İsrail oğullarında durum bambasskadır zirai işler için kọleye zaruri bir ihtiyaç yokłu. Zaten bunlar harp esirlerile borç yüzünden satılmış olanlardan ibaretti. Miktarlaları azdı ve onlara daha ziyade aile mensupları gözij ile bakilıd. Aile ibadetlerine onlar da ișiirak ederdi. (Huruç: 23,12 bab; 20,1; Tesniye : 16,11 $12,12)$. Bu görüs kölelere insani muamele edilmesini, himaye gösterilmesin: amirdi. (Huruç: bab 21,26 ;) bu himayenin en ileri şeklini Tesniyenin $(23 ; 15)$ cümlesinde görürüz:

«Efendisinden kaçıp sana gelen kulu efendisine teslim etmiyesin. Kendi beğendiği gibi senin şehirlerinden birinde kendi seçtiği mahalde aranızda seninle sakin olsun. Sen dahi ona eziyet etmiyesin»

\section{3 - Aile hukuku :}

Babilde aile monogami esasına dayanırdı. Çocuklanı olan evlilerin ayrılmaları ancak muhik sebeplerin vücudu halinde caizdi. 
Kadının durumu haylı düzenlenmiş, korunmuștu. Kocası memleketi terkeden kadın dilediğiyle evlenebilir ve kocasının ardeti halinde ona rücua mecbur tutulamazdı ( $\$ 136$ ). Cocuk sahibi olan bir karının boșanması halinde koca kendi mallarından, tarlasından, sürüsünden karının intifada devamına müsaade edecek, o karıdan olan çocukları yetiştirecek ve çocuklar büyüdüğü zamanda ise onlara vereceği șeylerden bir evlada düşen hisse miktarınt karıya tahsis edecekti. Buna mukabil kadın, seçtiği bir erkekle evlenmekte hürdü ( $\$ 137$ ). Keza, çocuğu olmayan bir kadının boșanmasında baba evinden getirdiği eşyası ve kadınlık bedeli (mihr) kendisine ödenecekti ( $\$$.138)

Kayıtsız şartsız boșama hali ancak kadınlık vazifelerini yapmayan, namusunu korumayan karılar hakkında idi. Mamafi bu halde koca isterse üstüne başka bir kadınla evlenerek onu hizmetçi gibi evinde yașatabilirdi. (\$ 141)

Buna mukabil, masum ve vazifesini bilen bir kadın, kocasının haksız muamele ve kötü hallerinden bizar olduğu takdirde onu istemeyebilir ve cihazını alıp baba evine gidebilirdi (\$ 142). Karı evlenirken kocasına bir odalık getirmisse koca üstüne başka bir kadın alamazdı (\$ 144). Karı bir illete müptelâ olmușsa koca üstüne bașka bir kadın alabilirdi. Su kadar ki hasta karıya da ömrünün sonuna kadar bakmakla mükellefti. İkametgâhını ve iașesini temin edecekti ( $\$ 148$ ). Görülüyorki durum haylı ileri bir medeniyet seviyesini göstermektedir.

Stuart Mill: «Bir medeniyetin seviyesini ölçmek isterseniz derhal kadinın hayat şartarına bakınız» der. Bu bakımdan Hamurabi kanununun değeri cidden yüksektir. Ancak, bu noktada kanunun kendi cemiyetinde ne dere- ceye kadar yaşamış, yürürmüş oduğunu da gene nazardan uzak tutmamak, araștırmak lâzımdır.

Babanın ailenin fertleri, hususile çocuklar üzerinde mutlak bir hakka sahipliği bahis mevzuu değildir. Hattâ babanın çocuğunu red etmesi, ancak çocuğun ağır bir suç ișlemesi ve bunun hakim kararile tesbiti halinde mümkündü (\$ 168) Hülâsa Babilde kuvvetli bir âmme intizamı ve merkeziyetçi ve muktedir bir krallığın vücudu aileyi, reisinin otoritesine sımsıkı bağlı olan kapalı ve küçük bir sosyal birlik halinde yaşamağa mahkûm olmakłan kurtarmıştır.

Israildeki durum nekadar başkadır: Bir kere Israil oğulları hiçbir zaman sağlam merkeziyetci bir devlet teșkil edememișlerdir. Camia bütün kuvvetini münferit ailelerin desteklemesinden alır. Bu itibarla ailenin disiplinli ve kuvvetli olması bir reisin mutlak otoritesi altında bulunması gerekir. Çocuk- 
lar ne kadar çok, aile nekadar kalabalık olursa okadar kuvvetli olur. Bu bakımdan poligamı asıldır. Kadının boșanma talebi, hakkı yoktur. Cemiyẹt ailenin dağılmasına müsaade edecek durumda değildir. Kan hısımlığı esası hakimdir. Aile reisi soyun ihtiyarları tarafindan yardım görmekle beraber, yine mutlak bir otoriteye sahiptir. Koca boșama hakkını keyfi bir surette kullanabilir. (Tesniye $24 ; 1$ ) Koca ancak iki halde bu hakkı gaip eder (Tesniye 22; 13-22,28) Bunlar kocanın, aldığı kıza bâkìr çıkmamak gibi bir iftirada bulunması veya bir kıza zorla tecavöz neticesinde onunla evlenmeye mecbur tutulması halleridir. Her iki halde koca artık ömrünce karısını boşayamaz, çünkü onu zelil etmiștir. Çok karılık esası kabul edildiğinden kısırlık mühim telâkki edilmemiștir. Ancak bir erkek, çocuk bırakmadan ölürse Levirat evlenmesi kabildir, yani erkeğ in kardeși dul yengesini alır ve ondan olan ilk çocuk ölen babaya izafe edilirdi (Tekvim: 8,38. Tesniye: 5,25) Bu sebeple Israilde evlâd edinme müessesesine rastlanmaz. Halbuki Babilde mevcuddur. Keza Israilde babanın çocukları üzerindeki nüfuzu pek fazla idi ve sertti (Huruç: $21 ; 15-17 ; 18$ ).

4 -- Ceza hukuku: Babilde yine merkeziyetçi ve teșkilaì muntazam işleyen bir devlet olması dolayısile, ceza hukukunun tatbiki devlete terettüp etmekte idi. Devlet suça kendiliğinden müdahale eder ve kanunlara itaati sağlardı. Kan gütme veya diyyet usuiü kalmamışłı. Halbuki merkezi bir teşkilâttan mahrum olan İsrail oğullarında ceza hukukunun tatbiki ailelere kalmışıı. Hatrâ katil suçunun kısası dahi mağdur tarafın ailesine aitti. Yani hayat ve sihhata karșı ișlenen en ağır suçlar dahi hususi suç karakterini arz ediyordu. Gerçi bu gibi suçları ayni zamanda büyük günahlar telâkki ederek yalnız şahıslara değil Allaha karşı işlenmis suçlar derecesine çıkarmak ve böylece ilahi nizamı muhafaza ile memur olan devleti fail ale; hine harekete getirmek de düșünülmüștür: fakat böyle kuvvetli bir devlet otoritesi mevcut olmadiğından suçluya cezasını vermek iși yine hususi intikam yoluna bırakllyyor demekti. Hurucun bu husustaki ıslahatı kan gütme usulünü keyfilikten kurtarmak, kan gütme hakkına sahip olan şahısların, ve aleyhine kan gütme yoluna baș vurulacak şahısların sayısını azaltmaktan ibaret kalmıştı. Bazı hallerde kan güłmenin yerine bir para alınniası da kaim olmuștur. Ve nihayet aleyhine kan gütme yoluna müracaat edilen kimselerin mabedlere kaçarak üluhiyetin himayesine sığınması esası da kabul edilmiştir. (Huruç; 1, 22; Tesniye : 4,19). Diğer taraftan kısas prensipinin yazilıs şekli dahi farklıdır. Israil kanununda kısas prerssibi doğrudan doğruya mutazarrıra hitap eder ve «zarar görürsen kısas edeceksin» der. 


\section{5 - Kanunlara hâkim olan ruh :}

Bundesbuch munhasıran hukukî kaidelerden ibaret değildir. Bunların yanıbaşında ve aralarında içtimai ahlâk kaideleri de vardır ve nihayet hepsi muayyen bir dünya görüsünün, muayyen bir dini akidenin muhtelif sahalardaki prensiplerinden ibarettir. Bu itibarla bu kanunlar herşeyden evvel ilâhidir, dinidir. Hurucun (21-23) bablerindeki talimatlar içinde içtimai hayatı ilgilendiren hükümlerle $(22,17:(23,12)$ sırf dini hükümler $(23,13 ;)(33,23)$ vardır. Hülâsa huruçtaki hükümler «theocratique» mahiyettedir. Halbuki Hamurabi kanunu tamamen dünyevî bir mahiyet arz eder. Zaten adı dâ «devlet için hukuk kaideleri» dir.

6 - Mevcut benzerliklerin izah vechi :

Evvelâ her hukuk sisteminde rastlanan benzerlikleri bir tarafa bırakmalıdır. Meselâ (huruç: 21,16$)$ le $(\$ 14)$ ve (huruç 21,18 ) ile (\$206) arasındaki müşabehet hayreti mucip bir ayniyet değildir. Bu gibi müșterek hükümlerden sarfınazar edilirse birbirine benzeyen hükümlerin doğrudan doğruya hukuk hayałı ile hiç de ilgili olmadıkları görülür. Bu müșterek hükümler yalnız birbirine benzeyen kelime ve şekilleri ihtiva etmektedir. Meselấ «huysuz öküz» misalinde ayni hal vardır. (Huruç: $21 ; 28,29$ ), (Hamurabi kanunu $\S 250, \S 251$ ) Bu tabirin hem Babil lisanında hem Israil dilinde müsterek bir halk tabiri olması muhtemeldir. Hattâ Israil kanun vazii bu tabiri Babil kanunundan iktibas etmis olsa bile, Tevrattaki hukuk kaidelerinin Babildeki hukuk kaidelerinden iktibas edilmiş olduğunu kabul imkânsızdır. Hukuk tarihi bize, hukuki terimlerin iktibasının daima hukuk müesseselerinin iktibasi demek olmadığını göstermektedir. Esasen bundan sarfınazar edilse bile zikri geçen tabiri ihtiva eden hükümler birbirlerine uymamaktadır. Kısas formülü hakkında da ayni şey söylenebilir. Nitekim buna benzer formüllere $M$. E VII inci yüz yıldaki Yunan hukukunda ve oniki lavha kanunlarında da rastlanır. Kısas kaidesile her iki kanunnamede birbirinden farklı gayeler takip edildiğine yukarıda işaret olunmuştu.

Formül itibarile birbirine benzeyen hükümlerden gayri olan müvazatın sebebi ise birçok kültür sahalarının birbirine karışmış olmasından ibarettir. Meselâ bütün eski sami milletlerde rastlanan evlenme akdi bugün (satış-evlenınesi) dediğimiz şekildedir ki bu, sümer kültüründen gelme bir iștirâk noktasıdır. Bununla beraber dışarıdan ayni görünen bu evlenme șekilleri arasında mahiyet ve muhteva itibarile farklar vardirki bu farklar ancak fertlerin bulundukları cemiyetin sosyal ve ekonomik durumu ile tesbit ve izah edilebilir. 
Hülâsa: Eski Babil hukuku İsrail hukukundan çok farklı idi. Arada mevcut müvazat hukuk kaidelerinin muhtevalarından ziyade, șekillerine aittir. Filhakika her iki milletin kanunlarının dayandıkları temeller birbirinden tamamen farklı idi. Bu sebeplerden dolayı Israil hukukunun nihayet Bundesbuch'un her hangi bir surette Hamurabi kanunundan iktibas edilmis olmasi ihtimali M. David'e göre inkânsızdır. Hatta burada sıkı bir karabetten dahi bahis edilemez. Böyle bir karabet olsa bile bununla ne hususi hükümler ne de kanunların muhtevaları veya sistemleri izah edilebilir. Bu fikir hakkında bazı tereddütler ileri sürülebilirse de hatłá Hamurabi kanunu ile Ahid arasında bir karabet mevcut olsa bile birbirine benzeyen veya birbirinin ayni olan bazı hükümlerden müșterek bir temel kanun fikrini istihraç etmek caiz değildir. Her halde mütaaddit sami milletlerin kadim tarihleri sarahaten malumumuz olmadıkça öyle bir görüș farzı ileri sürülemez.

Bu itibarla sözü geçen muvazata rağmen, M. DAViD, eski lsrail hukuku ve hususiyle Hurucun işaret edilen kısmı ile Hamurabi kanununun birbirlerinden müstakil olduğu fikrinaedir. «Bunlardan birini öbürüne irca etmek nasıl imkânsızsa, her ikisinin müșterek bir köke dayandiğını iddia etmekte aynı șekilde isbat edilemez." der.

III - Netice :

Kendilerine müracaat imkânını buláuğumuz mahdut menbalarla ulaștığımız netice tetkik mevzuundaki vesika kıtlığının ve bu mahdut vesikalar üzerinde yapılan sırf filolojik araștırmaların henüz kesin bir kanaata varmak imkânını vermediğini tesbitten ibarettir diyebiliriz,

Flhakika müelliflerin bir kısmı benzerlikler üzerinde, bir kısmı bașkalıklar üzerinde durmak suretiyle birbirlerine zıd sonuçlara varmışlardir. Uzerinde ekserisinin ittifak ettiği yegâne nokta Babil kanununun Tevrata doğrudan doğruya örneklik etmemiş olduğu hususudur. Her ikisinin de kendilerinden çok daha eski bir kaynaktan birbirlerinden habersizce istifade etmiş olmaları ihtmiali ise henüz ne reddi ne de isbatı kabil olamayan bir ipotezdir. Daha doğrusu bu mesele henüz münakaşa konusu olacak kadar olgun bir hale gelmemiștir. Hukuk tarihinin bu noktasını aydınlatacak vasita, meicut ve mahdut vesikalar üzerinde sırf şeklî ve filolojik metodlarla tekrar tekrar yapilacak incelemelerle bunlara dayanan münakaşalardan ziyade, kendilerine intizar ettiğimiz yeni vesikaların keșfi ve pek yeni keșfedilmiş olan bazı vesikaların da lâyikıyle tefsiridir. Son seneler içinde yapıldığını öğrenáiğimiz Irak hafriyatının, Hamurabi kanunu ve bunun arché-type'i hakkında bize yepyeni fikirler ilham edebileceği tahmin edilmektedir. Bu itibarla yeni hakikatlerin arifesinde bulunduğumuz bir anda mücerret iki eski kanun mec- 
muasının lafzî benzerlik veya bașkalıkları üzerinde durarak aceleci neticelere varmaktan çekinmemiz herhalde isabetli olur. Herhalde mürehassisJarın son sözlerini beklememiz gerekir.

Ancak, Her tarihî bilginin yeni keşifler tarafından tekzip edilmek tehlikesine maruz bulunduğu malûm bir șeydir. Bizim bu pek hususî tetkik konusunda yapmak istediğimiz şeyse, nihayet bütün varılan sonuç ve kanaatlan «bu güne kadar malûm olan hususlara göre» kaydıyle bağlamaktan iba rettir. Buraya kadar fikirlerini naklettiğimiz birbirine zıd kanaatlara sahip bilginler içinde Hollandalı bilgin M. DAVID'in görüşünün bilhassa hukuk sosyolojisi bakımından diğerlerinin fikirlerinden daha fazla hakikate yakın gibi göründüğünü kaydetmeden geçemiyeceğiz. Zira, alelıtlak iki ayrı cemiyete ait iki ayrı kanunnamenin mukayesesi yapılırken, herşeyden evvel bizzat bu cemiyetlerin karșılaștırılması, çeșitli sosyal faktörler, hukuk - içi ve hukuk - dışı unsurlar bakımından mukayesesi lâzımdır. Münhasıran iki kanunname metninin birbiriyle mukayeseleri hiç bir hakikate ulaștırmaz.

Lafzî mukayese metodunun negibi yanlışlıklara sebebiyet verdiğini tetkikimizin ilk kısmında göstermiștik. M. DAVID'in yaptığı ise, herșeyden evvel Babil ve Israil cemiyetlerinin bünye farkları üzerinde durmak olmușłur. Filhakika bu iki camia birbirinden o derece farklı idi ki, birinin diğerinin kanunlarından mülhem olarak kendisine has bir kanun yaratmıs olduğuna hükmetmek haylı güçtür. Meğerki bunu söz götürmez bir hakikat olarak ortaya koyacak harici vesikalar bulunmuş olsun. Yoksa sırf muhakeme ve istidlâl yóluyla böyle bir sonuca varmak hemen hemen kabil değildir,

Diğer tarafdan Hamurabi kanununun filen Babil cemiyetinde ve Babilin çökmesini müteakip onun yerine geçen diğer cemiyetlerde ne zamana kadar ve bilhassa ne nisbette tatbik edilmiş olduğu, ne dereceye kadar bir hukuk gerçekliği halini aldığı tesbit edilmedikçe bunun kendisinden sonraki kanun mecmuları üzerindeki müessiriyet derecesi anlaşılamaz. Hususiyle Hamurabi kanunnamesinin hiçbir zaman tatbik sahasına intikal etmediği, ancak güzel ve edebî bir tedvin örneği olarak yapıldığı yolundaki fikrin doğruluğu sabit olursa, bunun, kendisinden sekiz on asır sonraki bir kanun mecmuasına örneklik etmiş olması ihtimali büsbütün uzak görülür.

Ozerinde durulacak nokta nihayet arché-type meselesidir. $M$; DAVID bunu da reddetmektedir. Fakat, D. H. MOLLER'in bahsettiği bu mefruz archétype fiilen bir kazı neticesinde bulunduğu takdirde bundan, Tevratın, Hamurabi kanunu kanalıyla değil de, başka bir yoldan faydalanmıs olduğu hususu belki isbat edilebilir. 
Nitekim, Hamurabi Kanununun Sümer kanunlarından müteessir olduğu, ancak sümer kanunlarına nazaran, sami ırklara has serdliğin bazı âlâmerlerini tașıdığı ve bunun da Babilin Hamurabi hanedanının mensup olduğu sami milletlerle fazlaca işgal edilmiş olmasından ileri geldiği bugün umumiyetle kabul edilmiștir (52). Tevrat ise, Hamurabi kanununa nazaran büsbütün sami ruhun hakim olduğu bir kanun mecmuasıdır. Halen bulunmus veya ilerde bulunacak olan daha kadim bir kanunnamenin bu iki eski milletten hangisine maledileceği ve hangi ruhun ifadesini taşıyacağı șimdiden kestirilemez. Bu itibarla arché-type meselesi üzerindeki katî red hususu hariç olmak üzere, $M$. DAVID'in diğer fikirlerine iștirakte bir mahzur görmemekteyiz.

Hukukun sosyełenin kendi hususiyetlerini tașıyan bir mahsulü olduğu, ve kaçınılmaz bir şekilde onun bünyesine tabi bulunduğu bugün teslim edilmis bir şeydir. Bu bakımdan, Babil ve Israil hukuklarının mukayesesi demek, hem iki ayrı cemiyet hayatının, hem de hukuku teșkil eden örf âdet ve tałbikat neticelerinin mükayesesi demektir. Bunlar lâyıkiyle yapılmadıkça bu mesele hakkında esaslı bir şey söylenemez.

Incelediğimiz tetkiklerde ise tarihçi, filolog veya teolog olan muhtelif bilginlerin ancak kanunname metinleri üzerinde durduklarını ve «biblique» devirdeki vesika fıkdanının kendilerini böyle bir durumda kalmağa icbar ettiğini gördük. Kifayetsiz olduğuna hükmettiğimiz bu araștırmalardan $M$. David'in sosyolojik bakımdan temas ettiği hakikatleri doğru olarak kabul edip, meselenin daha fazla aydınlanmasını da yeni kazıların tefsirine talik etmekten başka yapacak bir șey olmadığına kani bulunuyoruz.

Hukuk Felsefesi ve Hukuk Sosyoloiisi Asistan Hâmide TOPÇUOĞLU 